\title{
Richard II and the Wider Gaelic World: A Reassessment
}

\section{Simon Egan}

\begin{abstract}
Although Richard II's Irish expedition of 1394-95 has attracted considerable scholarly attention, the focus has largely been on Richard's relations with the colonial administration in Ireland, pointing mainly to the colonial government's plea for greater royal investment in the colony as the main factor underpinning Richard's decision to intervene in Ireland. Little attention, by comparison, has been devoted to exploring the king's relations with both the Gaelic Irish and Gaelic Scottish nobility. Using Richard's relations with the expanding Gaelic world as the main case study, this article reconsiders how developments in the Gaelic west influenced the king's decision to intervene in Ireland. Set against the backdrop of Anglo-Scottish relations and the Hundred Years' War, the article draws on a broad range of Gaelic sources from Ireland and Scotland, English and Scottish governmental records, and material from the Avignon papacy. It uncovers and traces the development of the main Gaelic Irish and Gaelic Scottish dynasties during the late fourteenth century, their relationships with one another, and their unfolding connections with the English and Scottish crowns. By locating Richard's expeditions within the broader archipelagic context, this article argues that the wider Gaelic world, though on the geographic periphery of Ireland and Scotland, was capable of exerting a far greater degree of influence on the course of "British" politics than has previously been acknowledged.
\end{abstract}

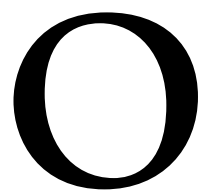

n 2 October 1394, Richard II (d.1400), king of England, landed at the port town of Waterford on the southeast coast of Ireland, commanding an army estimated at eight thousand in strength. It was the largest English military intervention in Ireland since the English conquest of the late twelfth century. Richard II's Irish expedition of 1394-95 has attracted a considerable amount of scholarly attention, yet much of the scholarship has focused on Richard's relations with the beleaguered colonial administration in Ireland. Historians have pointed almost solely to the Dublin government's pleas for greater royal investment in the Anglo-Irish colony, politically, financially, and militarily, as the main reason for Richard's decision to intervene in Ireland. ${ }^{1}$ However, securing the colony,

Simon Egan is a Society for Renaissance Studies Postdoctoral Fellow within the School of History at University College Cork. He thanks Dr. David Edwards, Mr. Kenneth Nicholls, and the anonymous readers of the Journal of British Studies for their comments that greatly improved this article.

${ }^{1}$ Michael J. Bennett, "Richard II and the Wider Realm," in Richard II: The Art of Kingship, ed. Anthony Goodman and James L. Gillespie (Oxford, 1999), 187-204, at 195-96, 202-4; Art Cosgrove, Late Medieval Ireland, 1370-1541 (Dublin, 1981), 10-20; Edmund Curtis, A History of Medieval Ireland from 1086 to 1513, 2nd ed. (London, 1938), 265-66; Seán Duffy, Ireland in the Middle Ages (Dublin, 1997), 158-59; Gerald Harriss, Shaping the Nation: England, 1360-1461 (Oxford, 2005), 511; James Lydon, The Lordship of Ireland in the Middle Ages (Dublin, 1972), 230-32; James Lydon, "Richard II's Expeditions to Ireland," 
particularly the southern marches, against the encroaching MacMurrough-Kavanaghs formed but one, albeit significant, aspect of Richard's Irish venture. ${ }^{2}$

The other main area of historical research relating to Richard II and Ireland has centered on the issue of the Gaelic submissions. It has generally been accepted that the submission of so many Irish lords (over eighty nobles submitted to Richard between January and April 1395) represented a growing willingness among the fractious Gaelic chieftains and wayward Anglo-Irish nobility to acknowledge the authority of the English crown. ${ }^{3}$ This interpretation nevertheless, represents an oversimplification of the submissions, the political realities pertaining to late fourteenthcentury Ireland, and the extent of English power there. Rather than receiving the submissions of a host of petty, fractious chieftains, Richard was in fact negotiating with an established aristocratic alliance network that had come to dominate much of the Irish political landscape. The four most powerful of these lords-O'Neill of Tyrone, O'Brien of Thomond, Burke of Clanrickard, and O'Connor Donn of Roscommon-between them controlled over a third of Ireland (see figure 1). Furthermore, it was largely through these "Big Four" (under the guidance of James Butler (d.1405), earl of Ormond) that Richard secured most of the other submissions.

Though historians have outlined various reasons for Richard's Irish expedition of 1394-95, such as the Irish council's plea of 1385 and the growing threat posed by the MacMurrough-Kavanaghs in southern Leinster, the preoccupation with Anglocentric source material has detracted from explorations of Richard's relations with the Gaelic nobility. ${ }^{4}$ Attempts at salvaging the Irish archival catastrophe of 1922 have yielded some promising results; the mainstay of recovered material nonetheless, deals with the Anglo-Irish colony. ${ }^{5}$ The notarial instruments used to record the

in Government, War and Society in Medieval Ireland: Essays by Edmund Curtis, A. J. Otway-Ruthven and James Lydon, ed. Peter Crooks (Dublin, 2008), 216-31, at 216-20; Darren McGettigan, Richard II and the Irish Kings (Dublin, 2016), 31-60, 93-120; Jocelyn Otway-Ruthven, A History of Medieval Ireland (London, 1980), 309-26; Nigel Saul, Richard II (Yale, 1997), 270-76; Brendan Smith, Crisis and Survival in Late Medieval Ireland: The English of Louth and their Neighbours, 1330-1450 (Oxford, 2013), 76-81; Anthony Tuck, Richard II and the Nobility (London, 1973), 170-71.

${ }^{2}$ For the MacMurrough-Kavanagh threat, see Robin Frame, "Two Kings in Leinster: The Crown and the MicMhurchadha in the Fourteenth Century," in Colony and Frontier in Medieval Ireland: Essays Presented to J. F. Lydon, ed. Terry Barry, Robin Frame, and Katharine Simms (London, 1995), 155-75, at $168-72$.

${ }^{3}$ Bennett, "Richard II and the Wider Realm," 196; Edmund Curtis, "Unpublished Letters from Richard II, 1394-5," Proceedings of the Royal Irish Academy C37 (1924-27): 276-303, at 281-82; Edmund Curtis, Richard II in Ireland, 1394-5: And Submissions of the Irish Chiefs (Oxford, 1927), 3235; Dorothy Johnston, "Richard II and the Submissions of Gaelic Ireland," Irish Historical Studies 22, no. 85 (March 1980): 1-20; Lydon, Lordship of Ireland, 237; Katharine Simms, From Kings to Warlords: The Changing Political Structure of Gaelic Ireland in the Later Middle Ages (Woodbridge, 1987), 34, 57, 70-72; J. A. Watt, "Gaelic Polity and Political Culture," in A New History of Ireland, vol. 2, Medieval Ireland, 1169-1534, ed. Art Cosgrove (Oxford, 1987), 314-51, at 344-45, 350; Saul, Richard II, 28182; Tuck, Richard II and the Nobility, 174-77.

${ }^{4}$ Statues and Ordinances, and Acts of the Parliament of Ireland: King John to Henry V, ed. Henry F. Berry (Dublin, 1997), 485-87; Cosgrove, Late Medieval Ireland, 17.

5 The destruction of the Four Courts in Dublin during the Irish Civil War (1922-23) resulted in the loss of innumerable documents relating to the history of premodern Ireland. For a guide to pertinent sources in the United Kingdom, see Brian Donovan and David Edwards, British Sources for Irish History, 1485-1641: A Guide to Manuscripts in Local, Regional and Specialised Repositories in England, Scotland and Wales 


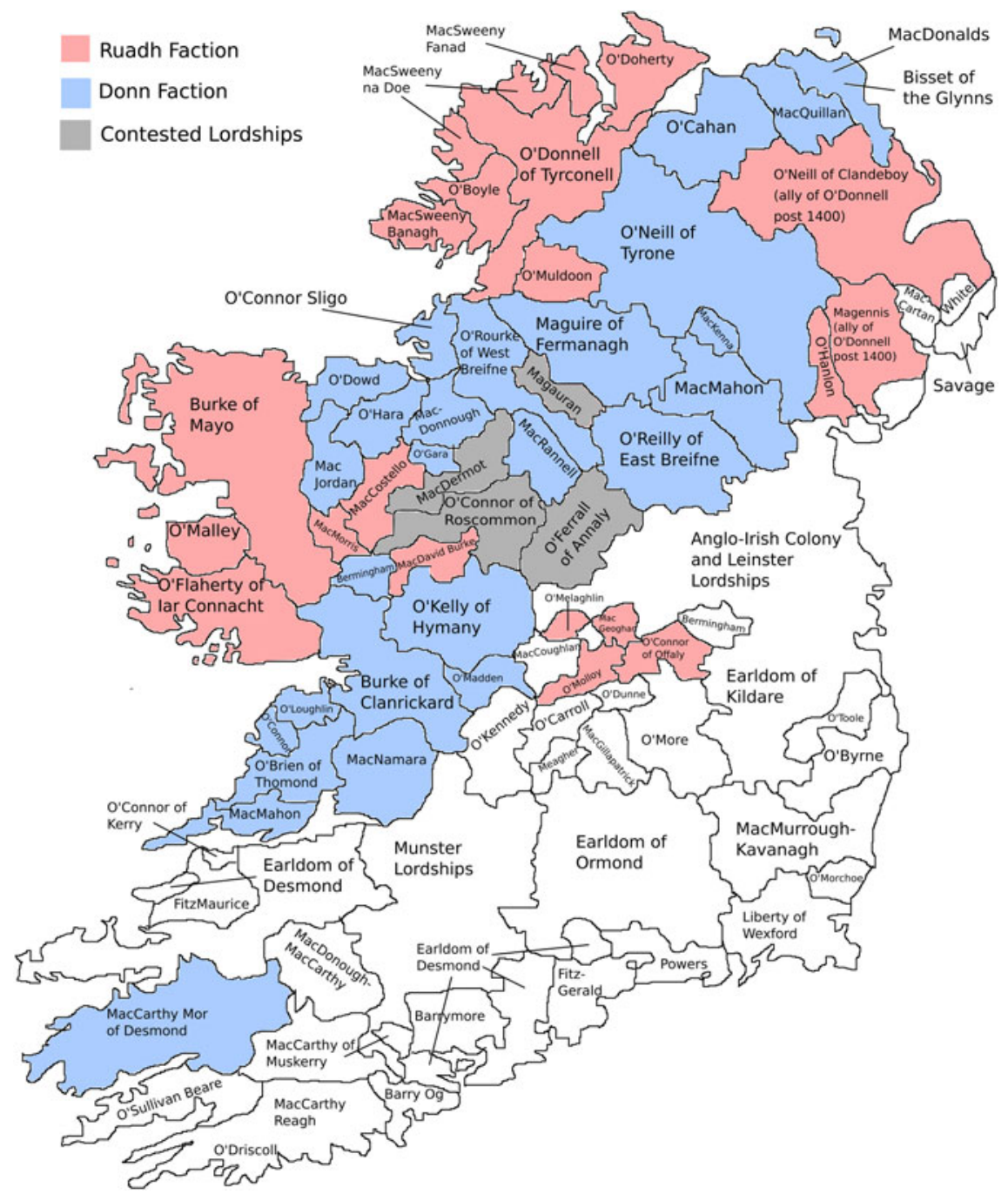

Figure 1-"Lordships in Ireland, c.1390." Note: This map is based on an earlier version compiled by Kenneth Nicholls; see Patrick J. Duffy, David Edwards, and Elizabeth FitzPatrick, "Introduction: Recovering Gaelic Ireland, c.1250-c.1650," in Gaelic Iveland, c.1250-c.1650: Land, Lordship and Settlement, ed. Patrick J. Duffy, David Edwards, and Elizabeth FitzPatrick (Dublin, 2001), 21-73, at 24-25.

submissions reveal little about the aims and ambitions of the foremost Irish dynasts. Contemporary chroniclers including Henry Knighton and Adam of Usk, though rich in detail on English domestic affairs, gloss over the king's Irish expedition and

(Dublin, 1997); Paul Dryburgh and Brendan Smith, eds., Handbook and Select Calendar of Sources for Medieval Ireland in the National Archives of the United Kingdom (Dublin, 2005). 
divulge nothing about his relations with the most powerful Irish lords. ${ }^{6}$ Much of John Froissart's material on the 1394-95 expedition remains apocryphal regarding Richard's dealings with the main Irish chieftains. ${ }^{7}$ The limitations of the English material are nonetheless offset by an abundance of Gaelic sources. These records, the corpus of annals in particular, reveal not only a great deal about the aims and ambitions of the Irish lords who submitted to Richard but are essential for exploring and contextualizing Richard's relations with elements of the wider Gaelic world. ${ }^{8}$

The submissions formed part of a much larger strategy of negotiation that extended beyond Ireland to Scotland. Richard's government had by 1390 established strong relations with the MacDonald lordship of the Isles that at the close of the fourteenth century had come to dominate much of the northern Irish Sea world and threatened to overrun large areas of the western Scottish Highlands. By negotiating with these Irish lords, as well as the highly militarized MacDonald lordship, Richard was in effect attempting to rebuild English power within the wider British Isles, albeit through non-English mediums. The only notable absentee from the submission lists, as many have remarked, was O'Donnell of Tyrconnell. ${ }^{9}$ The fact remains that O'Donnell did not submit in 1395, nor did his allies Burke of Mayo and O'Connor Ruadh of Roscommon (see figure 1). These three lords represented an alternative aristocratic network that rivaled the "Big Four" for control of much of Ireland's western seaboard. There is, moreover, considerable evidence that O'Donnell and his allies were aligned with the Stewart monarchy and the Avignon papacy.

Richard's negotiations with the Irish lords and the MacDonald lordship of the Isles thus need to be viewed within the broader context of developments within the wider Gaelic world, the course of Anglo-Scottish relations, and the Hundred Years' War. The king's relationship with the lords of the wider Gaelic world remains a fundamentally unexplored facet of his kingship. This issue is symptomatic of both the aforementioned reliance on English source material and current historiographical and methodological trends. The work of Rees Davies and Robin Frame has been instrumental in decoding the political development of late medieval Britain and Ireland, ${ }^{10}$ but their work, however pioneering, remains highly Anglo-centric in outlook; both scholars focus on the expansion of Anglo-French aristocratic culture, transnational landholding, and power in Ireland and the wider British Isles c.1100-c.1340. For the period c.1340-c.1460, the decline of pan-insular Anglo-French culture and

\footnotetext{
${ }^{6}$ Geoffrey Haward Martin, ed., Knighton's Chronicle, 1337-1396 (Oxford, 1995), 551; Chris Given Wilson, ed., The Chronicle of Adam of Usk, 1377-1421 (Oxford, 1997), 19; Henry Thomas Riley, ed., Johannis de Trokelowe, et Henrici de Blaneforde ... necnon quorundam anonymorum Chronicon et Annales (London, 1886), 172-73; George B. Stow, Jr, Historia Vitae et Regni Ricardi Secundi (Pennsylvania, 1977), 134-35.

7 Thomas Johnes, ed., Sir John Froissart's Chronicles of England, France, Spain and the Adjoining Countries: From the Latter Part of the Reign of Edward III to the Coronation of Henri IV, 12 vols. (London, 180310), 11:154-67. See also Johnston, "Richard II," 1-2.

${ }^{8}$ Rather than using the anachronistic term Gaeltacht, I have chosen the designation "wider Gaelic world," which, for the purpose of this article, signifies both the autonomous Gaelic-speaking regions of Ireland and Scotland and the acculturated "frontier" regions ruled by respective Anglo-Irish and Scottish magnates.

${ }^{9}$ Cosgrave, Late Medieval Ireland, 23; Tuck, Richard II and the Nobility, 176nl. John Watt stated that "all the Irish princes who mattered" submitted to Richard in 1395; see Watt, "Gaelic Polity," 324.

${ }^{10}$ Rees Davies, The First English Empire: Power and Identities in the British Isles, 1093-1343 (Oxford, 2000); Frame, Political Development.
} 
power, coupled with the deterioration of Anglo-Scottish relations, has led historians to move away from the "British Isles" model espoused by Davies and Frame toward the "Plantagenet" model of interpretation, locating the development of English power in Ireland, for example, within the context of the wider Plantagenet empire. ${ }^{11}$ Though offering useful insights into the inner workings of the AngloIrish colony, this approach has drawn attention further away from the Gaelic west. Historians of late medieval Scotland in comparison have, understandably, adopted a more national-centered approach when examining the consolidation of Bruce and early Stewart Scotland, albeit with limited consideration for Scotland's relations with Ireland. ${ }^{12}$

This present article argues for the continued worth of using the archipelagic model in exploring the political development of Britain and Ireland in the later fourteenth century-particularly when considering the role of the wider Gaelic world in influencing the course of "British" politics. Brendan Smith and Michael Brown have both outlined the value of utilizing such an approach when exploring inter-insular relationships between c.1300 and c.1460, though admittedly from respective Anglo- and Scottish-centric perspectives. ${ }^{13}$ Steven Ellis has drawn attention to the Gaelic world (or "Celtic fringe") as a force within late medieval "British" politics, yet his approach is likewise highly Anglo-centric in outlook. ${ }^{14}$ Believing the Gaelic resurgence of the fourteenth century to have been built upon "flimsy military foundations," Ellis has focused on the expansion of English power within the wider British Isles rather than assessing how developments within the wider Gaelic world could act as check on English expansion. ${ }^{15}$ Ellis's views on Gaelic identity have in turn drawn criticism from scholars such as Wilson McLeod and Martin MacGregor, who have both offered more nuanced readings on Gaelic cultural and political identity during the late medieval period. ${ }^{16}$ Yet McLeod's and MacGregor's models, though offering useful insights into concepts of Gaelic identity, ultimately lack a forensic examination of the hard political and dynastic structures underpinning Gaelic Irish and Gaelic Scottish interaction during the later medieval period.

By using Richard II's relations with the wider Gaelic world as a dedicated case study and by drawing upon a broad meld of material from within the Gaelic world, English and Scottish governmental records, and material from the Avignon papacy, this essay challenges the notion that events in the Gaelic west were peripheral

${ }^{11}$ Peter Crooks, "State of the Union: Perspectives on English Imperialism in the Late Middle Ages," Past and Present 212, no. 1 (August 2011): 1-40; David Green, "Lordship and Principality: Colonial Policy in Ireland and Aquitaine in the 1360s," Journal of British Studies 47, no. 1 (January 2008): 3-29.

${ }^{12}$ For example, see Stephen Boardman, The Early Stewart Kings: Robert II and Robert III (East Linton, 1996).

${ }^{13}$ Brendan Smith, "The British Isles in the Late Middle Ages: Shaping the Regions," in Ireland and the English World in the Late Middle Ages, ed. Brendan Smith (Basingstoke, 2009), 7-19; Michael Brown, Disunited Kingdoms: Peoples and Politics in the British Isles, 1280-1460 (Harlow, 2013).

${ }^{14}$ Steven Ellis, "The Collapse of the Gaelic World, 1450-1650," Irish Historical Studies 31, no. 124 (November 1999): 449-69.

${ }^{15}$ Ibid., 453, 457.

${ }^{16}$ Martin MacGregor, "Civilising Gaelic Scotland: The Scottish Isles and the Stewart Empire," in The Plantation of Ulster: Ideology and Practice, ed. Éamonn Ó Ciardha and Mícheál Ó Siochrú (Manchester, 2012), 33-54, at 38-40; Wilson McLeod, Divided Gaels: Gaelic Cultural Identities in Ireland and Scotland, c.1200-c.1650 (Oxford, 2004), 220-22. 
to the political development of late medieval Ireland and Britain. The first section explores Richard's relationship with the MacDonald lordship of the Isles and its significance for Irish affairs. The next section examines the context surrounding the emergence of the "Big Four" and their enemies in Ireland during the later fourteenth century and the way that this, in tandem with events in Gaelic Scotland, laid the foundation for Richard's expedition in 1394-95. The third and final section focuses on Richard's Irish venture of 1394-95, reassessing the submissions and his difficulties in achieving a permanent settlement in Ireland. The complexity of lineage-based societies and the fragmentary nature of surviving source material can make sifting through the dynastic world of Gaeldom appear to be an arduous task. The associated maps and tables, however, provide guides essential for locating each lordship geographically, tracing the development of each, and navigating the complex, dynastic milieu of the late fourteenth-century Gaelic world.

\section{GAELIC SCOTLAND IN THE LATE FOURTEENTH CENTURY}

It is rarely acknowledged that over the course of the later Middle Ages, nearly half the landmass of Britain and Ireland fell under autonomous Gaelic control. In Ireland, a combination of factors including the Bruce invasions (1315-18), the Black Death, a cooling of the climate, and the migration of Scottish mercenary galloglass to Ireland saw English power across the northwestern section of the island retreat significantly. Though Robin Frame has amply demonstrated that English power in Leinster and much of Munster was exercised effectively by the colonial earls, a good deal of the northern and western seaboard, including most of the de Burgh earldom of Ulster and lordship of Connacht, was lost to resurgent Irish dynasties or to the increasingly independent and acculturated Anglo-Irish Burkes of Clanrickard and Mayo. ${ }^{17}$

A similar process occurred in fourteenth-century Scotland, providing context crucial for exploring Richard II's later Irish venture. Robert Bruce's wars for control of Scotland in the early part of the century, coupled with the extinction of certain noble lines, brought about the disintegration of royal power in northern Scotland. ${ }^{18}$ As in Ireland, the political vacuum was filled by resurgent Gaelic clans such as the MacRuairís of Garmoran, the Clan Donnchaidh of Atholl, and the Clan Chattan of Lochaber and Badenoch, many of them migrating eastwards from the western highlands ${ }^{19}$ The most powerful Gaelic faction to emerge during the first half of the fourteenth century was the MacDonald lordship of the Isles. ${ }^{20}$ The lordship was comprised of numerous Hebridean and west highland kindreds, each subject to the nominal authority of the lord of the Isles, a direct descendant of Somerled (d.1164), king of the Hebrides (see figure 2). Over the course of the fourteenth

${ }^{17}$ See essays in Robin Frame, ed., Ireland and Britain, 1170-1450 (London, 1998).

${ }^{18}$ Boardman, Early Stewart Kings, 12-13; Alexander Grant, Independence and Nationhood: Scotland, 1306-1469 (London, 1984), 204-6.

${ }^{19}$ Stephen Boardman, "Lordship in the North-East: The Badenoch Stewarts, I, Alexander Earl of Buchan and Lord of Badenoch," Northern Scotland, 16 (May 1996): 1-30, at 2-3; Jean Munro and Robert Munro, eds., Acts of the Lords of the Isles, 1336-1493 (Edinburgh, 1986), xxx-xxxv, 4 (hereafter $A L I)$.

${ }^{20}$ Michael A. Penman, "The MacDonald Lordship and the Bruce Dynasty, c.1306-c.1371," in The Lordship of the Isles, ed. Richard Oram (Leiden, 2014), 62-87, at 70-80. 
and fifteenth centuries, the lordship of the Isles became a major political force within the Gaelic world and also on the wider "British" stage. This powerful position rested chiefly on the lords of Isles' ability to raise considerable military and maritime resources from the various sub-kindreds. ${ }^{21}$ Though the lordship crumbled apart in the late fifteenth century, largely due to internecine struggles and growing royal Scottish encroachment, successive lords of the Isles were able to maintain the relative cohesion of the wider lordship until the mid-fifteenth century.

It was under the leadership of John MacDonald of Islay (d.1387), the first lord of the Isles, that the lordship emerged as a potent force within the Irish Sea world. The lordship's strategic position made it an ideal ally of the English crown, and from the late 1330s to the late 1360s John was courted by Edward III of England and by Edward Baliol, the pro-English claimant to Scotland. ${ }^{22}$ These accords proved mutually beneficial. On one level, they helped safeguard England's northern frontiers with Scotland during the early decades of the Hundred Years' War. ${ }^{23}$ They also served to protect the east coast of Ulster from Scottish intervention. For John, the accords gave him a freer hand to continue expanding across large areas of northern Scotland, as well as the opportunity to meddle in affairs in Ireland, where he had considerable interests.

Sometime during the early 1330s, John allegedly exiled his cousins, the Clan Alexander, to Ireland. ${ }^{24}$ There they were subsequently forced to become mercenary galloglass, serving the expansionist O'Neills of Tyrone, then led by Aodh Reamhar O'Neill (d.1364). Though the record is fragmentary, it appears that John became concerned that the Clan Alexander, with O'Neill support, would attempt to retake IslayJohn's seat of power. ${ }^{25} \mathrm{He}$ quickly set about shoring up alliances in both Scotland and Ireland. In 1337 he married Amy MacRuairí, sister of Ruairí MacRuairí of Garmoran, the most powerful lord in the northern Hebrides-a match that secured him possession of the northern Hebrides following Ruairís assassination in 1346 (see figure 2). ${ }^{26}$ In Ireland John moved to cultivate links with the O'Neills' Irish enemies and the English administration. In 1335 he had traveled to Drogheda to assist in preparations for an attack on Scotland. Three years later he successfully petitioned Edward III (d.1377) to allow his cousins, Hugh and John Bisset, to acquire possession of the Antrim-based barony of Larne and Isle of Rathlin respectively (see figure 2). ${ }^{27}$ John also secured from Edward III a number of safe passes to allow himself and

${ }^{21}$ Simon Kingston, Ulster and the Isles in the Fifteenth Century: The Lordship of the Clann Dombnaill of Antrim (Dublin, 2004), 184-201.

${ }^{22}$ For example, see ALI, 1-4; Joseph Bain, ed., Calendar of Documents Relating to Scotland, vol. 3, Edinburgh, 1881-88, 232n1272; David MacPherson, ed., Rotuli Scotiae 1292-1516 (hereafter Rot. Scot.), 2 vols. (London, 1819), 1:516, 534-35, 677.

${ }^{23}$ Alastair MacDonald, Border Bloodshed: Scotland, England and France at War, 1369-1403 (Edinburgh, 2000), 32 .

${ }^{24}$ Noel Murray, "A House Divided against Itself: A Brief Synopsis of the History of Clan Alexandair and the Early Career of 'Good John of Islay,' c.1290-1370," in Rannsachadh na Gáidhlig 2000, ed. Colm Ó Baoill and Nancy R. McGuire (Aberdeen, 2002), 221-30, at 223-25.

25 Ibid., 221-30.

${ }^{26}$ ALI, 242; James MacPhail, ed., Highland Papers (hereafter HP), 4 vols. (Edinburgh, 1914-34), 1:74; HP, 1:17; Joseph Amours, John Thomas, and George Neilson, eds., The Original Chronicle of Andrew of Wyntoun, 6 vols. (Edinburgh, 1903-14), 6:174.

${ }^{27}$ James Brown Dougherty ed., Reports of the Deputy Keeper of the Public Records of Ireland, vol. 44 (Dublin, 1896-1912), 61; Henry Churchill Maxwell Lyte, ed., Calendar of Patent Rolls: Edward III, 1327-1377, 16 vols. (London, 1893-1916), 4:81. Robin Frame, English Lordship in Ireland, 1318-1361 


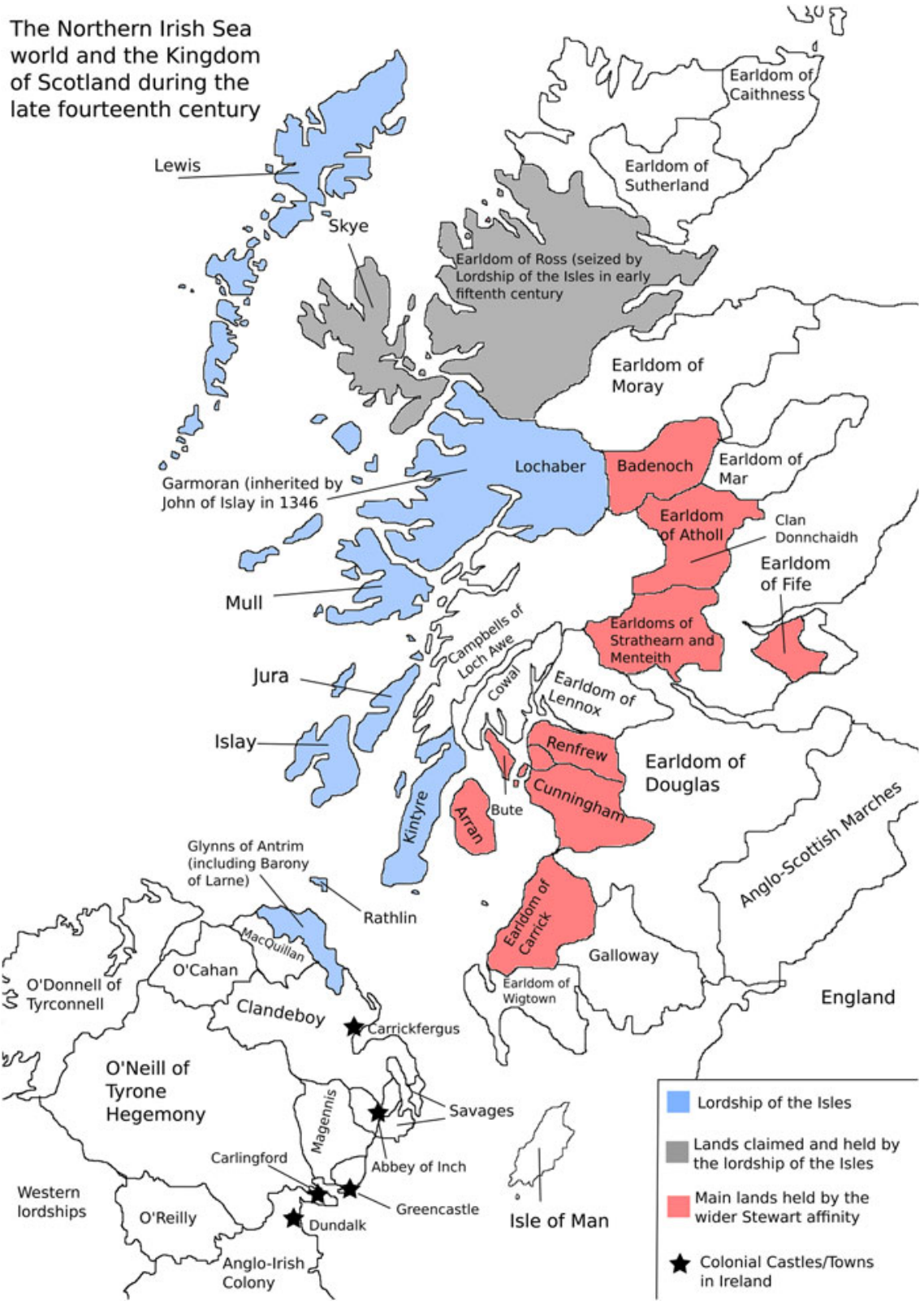

Figure 2-"The Northern Irish Sea World and the Kingdom of Scotland during the Late Fourteenth Century." Note: This map is based on an earlier version compiled by Michael Brown; see The Wars of Scotland, 1214-1371 (Edinburgh, 2004), 317.

(Oxford, 1982), 144-52; Smith, Crisis and Survival, 31; Bain, Calendar of Documents Relating to Scotland, $3: 232 \mathrm{n} 1272, \mathrm{nl} 276$ 
his mother, Áine, the daughter of O'Cahan, to travel between Scotland and Ireland in 1337 and $1338 .{ }^{28}$

Áine was a member of the O'Cahan kindred whose lordship was located on the northern coast of Ulster, bordering the O’Neill lordship of Tyrone (see figure 2). She had married, c.1300, John's father, Angus Óg-a previous lord of Islay who fell at the Battle of Faughart during the Bruce Invasions of Ireland in 1318. ${ }^{29}$ Soon after the granting of the 1338 pass, Áine married Murtagh Ceannfhada O'Neill (d.1395), the brother of the lord of the Clandeboy O'Neills, Brian (d.1369). The Clandeboy O'Neills were regional rivals of the Tyrone branch and contested the Tyrone's branch's claim to the chieftaincy of the wider O'Neill kindred (see figure 2). ${ }^{30}$ As allies of the colonial government, Brian and his brother Murtagh Ceannfhada acted as a check on the territorial ambitions of Aodh Reamhar O'Neill, lord of Tyrone and patron of the Clan Alexander. By drawing the O'Neills of Clandeboy and O'Cahans closer to one another, John created a buffer between himself and the Clan Alexander, while at the same time helping to protect the earldom of Ulster, now confined to an increasingly narrow strip of land hugging the southeast coast of Ulster. Moreover, John is recorded as leading two expeditions to Ireland (probably in the mid-1340s) in an attempt to secure the O'Neill chieftaincy for his cousin, Brian; both ventures failed. ${ }^{31}$

Despite the highly fragmentary nature of surviving source material, it appears that relations between the lordship of the Isles and the O'Neills improved during the last two decades of the fourteenth century. The reconciliation of the O'Neills of Tyrone and Clandeboy during the late 1360s undoubtedly contributed to this process. ${ }^{32}$ Developments in the western section of Ireland-namely, the rise of the O'Donnells-played an equal if not more important role in strengthening ties between the O'Neills of Tyrone and the Islesmen (and are discussed in greater detail below). It is also worth noting here that by the late 1370s the Clan Alexander had fragmented into a series of sub-kindreds. Though the main sept remained in the employ of the O'Neills of Tyrone, the smaller family branches migrated westward into Connacht. Here they sought and eventually found employment with kindreds allied to the O'Donnells. ${ }^{33}$ There is evidence (outlined below) to suggest that the O'Donnells had by the early 1380s drifted into the orbit of the Scottish crown. John of Islay thus may have feared becoming stretched on two fronts, with the O'Donnells and the Clan Alexander in the west, and the Scottish monarchy in the east. Relations between the O'Neills of Tyrone and the lordship of the Isles gradually improved as both faced a common enemy in Ireland. Against the backdrop of the

${ }^{28}$ Rot. Scot., 1:516, 534-35.

${ }^{29}$ HP , 1:20; Alexander Cameron, ed., Reliquiae Celticae, 2 vols. (Inverness, 1892-94), 2:158-59.

${ }^{30} \mathrm{HP}, 1: 20,27$. For Clandeboy ties to Dublin, see Smith, Crisis and Survival, 30-31.

${ }^{31} \mathrm{HP}, 1: 27$.

${ }^{32}$ For reconciliation, see Simms, "Late Medieval Tír Eoghain," 147-48.

${ }^{33}$ William Hennessy and Bartholomew MacCarthy, ed., The Annals of Ulster (hereafter $\left.A U\right), 4$ vols. (Dublin, 1887-1901), 1384; John O'Donovan, ed., Annals of the Kingdom of Ireland (hereafter AFM), 7 vols. (Dublin, 1990), 1397; Martin Freeman, ed., Annála Connnacht, 1224-1544 (hereafter AC) (Dublin, 1970), 1398; William Hennessy, ed., Annals of Loch Cé (hereafter ALC), 2 vols. (London, 1939), 1397, 1398; Nicholls, "Scottish Mercenary Kindreds," 100. (It is general practice in medieval Irish history studies to give annals references as year rather than volume or page number.) 
Hundred Years' War, the government of Richard II sought to exploit this shift in Gaelic realpolitik through negotiation with the O'Neills and their allies (a topic discussed below, in the final section) and by allowing a more permanent MacDonald presence in Ulster.

The death of David II in 1371 and the accession of Robert Stewart (d.1390) as Robert II led to a brief period of rapprochement between the lord of the Isles and the Scottish crown. Unlike David, Robert enjoyed more cordial relations with his Gaelic-speaking subjects. Originally hailing from western Scotland, he was acculturated to Gaelic Scotland and able to move easily between the Gaelic and ScotsEnglish-speaking worlds. ${ }^{34}$ In fact, much of his support base within the kingdom derived from Gaelic kindreds, such as the Campbells of Loch Awe, the Clan Donnchaidh of Atholl, and the lordship of the Isles. ${ }^{35}$ Married to Robert's daughter Margaret in 1350, John had aligned himself with the Stewarts during David II's protracted captivity (1346-57) before drifting back into English allegiance upon David's return to Scotland in $1357 .{ }^{36}$ As a son-in-law of the new king in 1371, John perhaps hoped to secure legitimization for his "acquisitions" in northern Scotland. ${ }^{37} \mathrm{~A}$ combination of factors, however, placed great pressure on his relationship with the new regime. As suggested by Alexander Grant, John may have expected to have been awarded a grant of royal lieutenancy over much of western Scotland; instead the lieutenancy was awarded to Gillespic Campbell of Loch Awe, one of John's main regional rivals. ${ }^{38}$ The far more damaging rift, however, occurred in northern Scotland, where Robert II failed to curtail the activities of his son, Alexander Stewart, the infamous "Wolf of Badenoch," whose forces continually raided John's holdings in Lochaber (see figure 2). ${ }^{39}$

Within a few years, tensions between John and the crown had risen once again. With little recourse, John had by the late 1370s revived his alliance with the English government. ${ }^{40}$ Once more this arrangement proved mutually beneficial. The renewal of the Hundred Years' War in 1371, the advent of Franco-Castilian naval supremacy, and Robert II's commitment to the French meant that English holdings within the Irish Sea world were vulnerable to French and Scottish attack. $^{41}$ For example, during the 1370s, the English government feared that Owain Lawgoch (d.1378), a Welshman in French military service and the self-proclaimed Prince of Wales, would return to Wales and launch a major revolt with

${ }^{34}$ Stephen Boardman, "The Gaelic World and the Early Stewart Court," in Miorún Mór nan Gall: The Great Ill-Will of the Lowlander, ed. Dauvit Broun and Martin MacGregor (Stornoway, 2007), 83-109.

${ }^{35}$ Boardman, Early Stewart Kings, 7, 28n31; Boardman, "The Gaelic World," 101.

${ }^{36}$ For marriage, see $A L I, 242$. For overview of English alliance, see Penman, "Bruce Dynasty," 75-87.

${ }^{37}$ Boardman, Early Stewart Kings, 90-91; Alexander Grant, "Scotland's 'Celtic Fringe' in the Late Middle Ages: The MacDonald Lords of the Isles and the Kingdom of Scotland," in The British Isles, 1100-1500: Comparisons, Contrasts and Connections, ed. Rees Davies (Edinburgh, 1988), 118-41, at 126-27.

38 Ibid.

${ }^{39} \mathrm{HP}, \mathrm{1}: 25$; Boardman, "Badenoch Stewarts I," 1-30.

${ }^{40}$ Rot. Scot., 2:11, 45; ALI, 297.

${ }^{41}$ MacDonald, Border Bloodshed, 31-32; Jonathon Sumption, The Hundred Years War, vol. 3, Divided Houses (London, 2009), 115-70. The English Commons had become concerned about the decline of English sea power in this period. See Rotuli Parliamentorum, 6 vols. (London, 1767-77), 2:311. 
French support. ${ }^{42}$ Despite Lawgoch's assassination at Mortagne in 1378, Richard II's government remained concerned about French intervention along the southern coasts of England and Wales well into the 1380s. ${ }^{43}$ English possessions in Ireland were also subject to French and Scottish attack. In 1381 the port town of Kinsale on the southwest coast of Ireland was raided by a large Franco-Castilian force commanded by Jean de Vienne (d.1396), the admiral of France and architect of French naval supremacy. ${ }^{44}$ Richard subsequently approved funds for the walling of Kinsale to protect the inhabitants from further attack. ${ }^{45}$ The port of Waterford was likewise raided by Castilian forces in 1377, while the city of Cork and its hinterland in 1388 are recorded as suffering numerous burnings at the hands of Irish rebels and the king's enemies. ${ }^{46}$ More striking still is that in 1388 (a year after John's death) a large Scottish force commanded by Sir William Douglas of Nithsdale (d.1391) ravaged colonial settlements at Carlingford Lough before raiding the Isle of Man as part of the broader Otterburn campaign. ${ }^{47}$

These attacks capitalized upon the English entanglement on the European continent, particularly during the mid-1380s, when English forces had become increasingly ensnared in the Iberian Peninsula. ${ }^{48}$ Though the earldom of Ulster had by this time shrunk to a thin strip of coastline, it appears to have remained economically viable due to a lucrative fishing trade operating from Strangford Lough, Carlingford, and the Abbey of Inch (see figure 2) ${ }^{49}$ Moreover, the defense of Carrickfergus Castle remained of paramount importance both to the Crown and Irish Council; in 1392 it was feared that Carrickfergus would fall to the Gaelic Irish, and the justicar, Sir John Stanley (d.1414), received orders to reinforce the castle's defenses. ${ }^{50}$

John's considerable military and maritime resources offered a greater degree of protection to English holdings north of Wales, especially the castles and fisheries of eastern Ulster. Prior to his removal from governance in 1387, Richard II took steps to secure a greater MacDonald presence in Ulster. On 16 February 1387 a license was granted by the Irish Council for the marriage of Robert Savage to Christina, a daughter of John, lord of the Isles. The marriage was subsequently ratified by the English Council on 4 May 1388..$^{51}$ The identity of Robert Savage is uncertain, but, as Katharine Simms has suggested, he was most likely the son of the previous crown seneschal of Ulster, Robert (d.1360) and brother of the current seneschal,

\footnotetext{
42 See also Anthony Carr, Owen of Wales: The End of the House of Gwynedd (Cardiff, 1991).

${ }^{43}$ For English security concerns relating to Wales, see Rees Davies, The Revolt of Owain Glyn Dwr (Oxford, 1995), 83-87.

${ }^{44}$ David Preest and James G. Clark, eds., The Chronica Maiora of Thomas Walsingham, 1376-1422 (Woodbridge, 2005), 108-9.

${ }^{45}$ Edward Tresham, ed., Rotulorum Patentium et Clausorum Cancellariae Hiberniae Calendarium (hereafter $R C H$ ) (Dublin, 1828), 114n193.

${ }^{46}$ Brendan Smith, "Late Medieval Ireland and the English Connection: Waterford and Bristol, ca. 1360-1460," Journal of British Studies 50, no. 3 (July 2011): 546-65, at 554. For Cork, see Henry Churchill Maxwell Lyte, ed., Calendar of Close Rolls: Richard II, 1377-1399 (hereafter CCR, Richard II), 6 vols. (London, 1914-1927), 3:521-22.

${ }^{47}$ RCH, 127n243; Amours, Thomas, and Neilson, Chronicle of Andrew of Wyntoun, 321-24.

48 Sumption, Divided Houses, 558-623.

49 Timothy O’Neill, Merchants and Mariners in Medieval Ireland (Dublin, 1987), 30-33.

${ }^{50}$ Henry Churchill Maxwell Lyte, ed., Calendar of Patent Rolls: Richard II, 1377-1399 (hereafter CPR, Richard II), vol. 4 (London, 1902), 405.

${ }^{51}$ RCH, 137n218; CPR, Richard II, 3:435.
} 
Edmund (fl.1385). ${ }^{52}$ Based in the Ards Peninsula and originally of Anglo-Norman extraction, the Savages had defended the declining earldom of Ulster from O'Neill expansion for much of the earlier fourteenth century. Despite a brief spell of disfavor in the 1370s, the Savages had reestablished themselves during the early 1380s as key agents of both the English crown and the Mortimer earls of March. ${ }^{53}$ There is evidence to suggest that the Savages were highly acculturated to the sociocultural world of Gaelic Ireland, and by association, of Gaelic Scotland. For example, a Jenkin Savage, possibly a brother of Robert (d.1360), was a noted patron of Gaelic bards - this would help explain and contextualize their cordial relations with the lord of the Isles. ${ }^{54}$ The Savage match of 1387 formed the basis for further MacDonald expansion in Ireland, which again served the purposes of the both MacDonalds and the English crown. By 1387, John of Islay was an old man; he was probably in his late eighties and had ruled the Isles successfully for more than fifty years. He may, however, have been concerned regarding the succession of the lordship. ${ }^{55} \mathrm{It}$ has been suggested that following his death later that year, there may have been a very brief period of interregnum in the lordship of the Isles, and that there was some opposition among the island kindreds to the succession of his heir designate, Donald (d.1423), the grandson of Robert II. ${ }^{56}$

The council of the Isles (comprising the chiefs of the main island kindreds) soon agreed to support the decision of Ranald-John's eldest son by his first marriage to Amy MacRuairí-who had been acting as the caretaker lord of the Isles until Donald was ready to take power. ${ }^{57}$ In any case, there was a brief period during which the lordship of the Isles may have been vulnerable to a dynastic challenge from the Scottish monarchy or their recent Irish allies, the O'Donnells. ${ }^{58}$ The marriage of Christina (Donald's sister) and Robert Savage gave the new lord of the Isles a greater foothold in Ireland and formed the basis for the subsequent MacDonald acquisition of the Seven Glynns of Antrim. The precise dating of the MacDonald acquisition of the Glynns- brought about by the marriage of Donald's brother, John Mór (d.1427) (son of John of Islay and Margaret Stewart) to Marjory Bisset, the heiress to the Glynns - remains uncertain. John had certainly secured possession of the Glynns in 1400, owing to the fact that he is styled as lord thereof in correspondence with the English crown. ${ }^{59}$ Though historians have gravitated toward this later date, by broadening the scope of investigation it becomes possible to posit an earlier date for the acquisition.

${ }^{52}$ Katharine Simms, "The Ulster Revolt of 1404: An Anti-Lancastrian Dimension?," in Ireland and the English World in the Late Middle Ages, ed. Brendan Smith (Basingstoke, 2009), 141-60, at 157.

${ }_{53}^{3}$ For the Savages' earlier service, see Robin Frame, "Power and Society in the Lordship of Ireland, 1272-1377," in Ireland and Britain, 1170-1450, ed. Robin Frame (London, 1998), 191-220, at 196; Robin Frame, "Military Service in the Lordship of Ireland, 1290-1360: Institutions and Society on the Anglo-Gaelic Frontier," in ibid., 279-99, at 241-42.

${ }^{54} A U, 1374$.

55 Ibid., 1387.

${ }^{56}$ Kingston, Ulster and the Isles, 34-35.

${ }^{57}$ Reliquiae Celticae, 2:161.

58 See below for O’Donnell links to the Clan Alexander.

${ }^{59}$ Rot. Scot., 2:155-56. John Mór received an indenture for the Antrim lands in 1403; see Kingston, Ulster and the Isles, 50n100. 
Allowing for a greater degree of MacDonald influence in Ulster was part of a broader "British"-oriented defensive system orchestrated by Richard II, though a rarely acknowledged aspect of his kingship. ${ }^{60}$ Through the promotion of loyalist servitors and by forming alliances with non-English mediums, such as the lordship of the Isles, Richard hoped both to secure his own personal rule and rebuild English power within the wider British Isles. For example, as Prince of Wales, he enjoyed a strong support base among the native Welsh and colonial communities. He also promoted strong relations with the port town of Chester and in 1392 granted possession of the strategic Isle of Man to the loyalist William Scrope (d.1399). ${ }^{61}$ Ireland, nonetheless, continued to pose a significant challenge due to the lack of effective English royal power beyond the colony and the increasing level of aristocratic factionalism among the Anglo-Irish community. ${ }^{62}$ Negotiating with the wider Gaelic nobility, the MacDonalds in this instance, and their capacity to raise considerable military resources in regions beyond effective English influence, offered Richard a solution.

In October 1389, a year after Richard reassumed power, Edmund Savage was granted the wardship of the heiress Marjory Bisset and her sister Elizabeth-both daughters of the recently deceased "Hugh Byset"-with permission to marry them to any of the king's loyal lieges. ${ }^{63}$ While no record provides a date for the union of John Mór and Marjory, it is possible that the match may have occurred as early as 1390. Surviving proclamations of Anglo-French treaties between August 1389 and March 1396 name John Mór ("Jehan de Ysles" or "Johan des Isles") as an ally of the English crown. ${ }^{64}$ The fact that the actual lord of the Isles, Donald, is not included suggests that John Mór had become the main intermediary between the crown and his brother and may have been engaged in negotiations with the crown and Savages as early as 1389, settling soon after as the de facto lord of the Glynns. ${ }^{65}$

The marriage not only secured a lasting MacDonald presence in Ulster but may also have helped to mend relations with the O'Neills of Tyrone. Numerous Irish annals indicate that the head of the Bisset affinity-MacEoin Bisset-was married to Sadhb (d.1387), daughter Aodh O’Neill-quite probably Aodh Reamhar O'Neill, which would make her a sister of the O'Neill chieftain Niall Mór (d.1397). ${ }^{66}$ Owing to a mistake in the English translation of the Annals of the Four Masters, there is no record of MacEoin Bisset's first name. ${ }^{67}$ It is therefore very

${ }^{60}$ See Tuck, Richard II and the Nobility, 164.

${ }^{61}$ For the importance of these regions, see Bennett, "Richard II and the Wider World," 187-204; Saul, Richard II, 172, 187, 393-94; Tuck, Richard II and the Nobility, 62, 82, 180.

${ }^{62}$ Peter Crooks, "The 'Calculus of Faction' and Richard II's Duchy of Ireland," in Fourteenth Century England, vol. 5, ed. Nigel Saul (Woodbridge, 2008), 94-115.

${ }^{63} \mathrm{RCH}, 146 \mathrm{nl} 98$.

${ }^{64}$ Thomas Rymer, ed., Foedera, 20 vols. (London, 1727-35), 7:622-29, 639-40, 656-58, 714-16, 777,824 .

${ }^{65}$ The English crown was also in separate contact with Donald (and his half-brother Godfrey of Uist) via the Bishop of Sodor; see Rot. Scot., 2:94-95; Foedera, 2:592; CPR, Richard II, 5:181.

${ }^{66}$ For her obituary, see $A C, A U, A L C, A F M, 1387$; Dennis Murphy, ed., The Annals of Clonmacnoise (hereafter AClon) (Dublin, 1986), 1387. The annals also refer to Aodh Óg O’Neill, who was allied to MacEoin Bisset, whether as brother-in-law or father-in-law is uncertain $(A U, 1383)$; to an Aodh na Fiodhbhaighe whose son died in 1358 (AFM, 1358); and to an Aodh son of Ruairí O’Neill, who died in 1353 (ALC, 1353).

${ }^{67}$ The editor John O'Donovan's misinterpretation of the surname MacEoin Bisset has given rise to the idea that he was called John; see $A F M, 1387$. 
possible that "MacEoin Bisset" and the aforementioned "Hugh Byset," father of Marjory and Elizabeth, were one and the same. This would in turn mean that Marjory was the niece of Niall Mór O’Neill and would suggest a familial link between all three dynasties.

The territorial aggrandizement of the MacDonalds in Antrim would form a central aspect of Richard II's Irish strategy. Though nominally at peace with Scotland and France since 1389, the lordship of the Isles' ability to check Scottish expansion in the northern Irish Sea world allowed Richard to direct his full attention to Ireland. Here he could pursue the recovery of the Mortimer inheritance and the reduction of forces hostile to English interests therein-particularly in the west of Ireland. The idea that the O'Neills of Tyrone had a vested interest in the MacDonald acquisition of Antrim is also reinforced by developments in Ireland west of the River Shannon. Therefore, in order to understand the broader context behind both the cooling of O'Neill-MacDonald tensions and the background to Richard's Irish expeditions, it is necessary to first trace the political development of Gaelic Ireland's western seaboard at the close of the fourteenth century.

\section{GAELIC IRELAND IN THE LATE FOURTEENTH CENTURY}

The Annals of Connacht record that on 25 November 1384, Ruairí O’Connor, king of Connacht, died from plague. ${ }^{68}$ The earlier fourteenth century had witnessed growing tensions and divisions within the O'Connor lordship of Roscommon. Contemporary annalists, however, credited Ruairís sixteen-year reign as allowing for a greater degree of stability and political cohesion within the wider O'Connor lordship. ${ }^{69}$ Indeed, his death has been described by Kenneth Nicholls as causing "the fatal division" of the O'Connor' lordship into the two dominant, competing lines of O'Connor Ruadh and O'Connor Donn. ${ }^{70}$ Following Ruairi's death, two rival claimants to the vacant kingship were proclaimed almost immediately. Turlough Óg O'Connor Donn (d.1406) (a nephew of Ruairí and son of Ruairís predecessor, Aodh d.1356, son of Turlough d.1343/5) was elected king of Connacht by the O'Connor Donn kindred, their kinsmen the O'Connors of Sligo, the O'Rourkes of Breifne, the O'Kellys of Hymany, the MacDermots of Airteach and the Burkes of Clanrickard. ${ }^{71}$ Conversely, Turlough O'Connor Ruadh (d.1425/6) - a second cousin of Turlough Óg O'Connor Donn and son of Aodh (d.1368), son of Felim (d.1316) —was supported by the MacDermots of Moylurg, the O'Malleys of the Owles and the Burkes of Mayo. O'Connor Donn and O'Connor Ruadh's alliance networks (including lesser kindreds) are depicted on the table and map below (see table 1 and figure 1). For the purpose of this essay, these alliance networks are referred to as the Donn and Ruadh factions, terms originally coined by Kenneth

${ }^{68} A C, 1384$.

${ }^{69} A C, A U, A L C$, AClon, AFM, 1384.

${ }^{70}$ Kenneth Nicholls, Gaelic and Gaelicized Ireland in the Middle Ages, 2nd ed. (Dublin 2003), 174.

${ }^{71} A C, A U, A L C, A C l o n, A F M, 1384$. The MacDermots of Airteach were a rival branch of the main Moylurg line and eventually died out in the sixteenth century. Their lordship was located in the western section of County Roscommon; see $A F M, 1405,1416$; $A C, 1416$. 
Table 1-Donn/Ruadh allegiance within Connacht

\begin{tabular}{|c|c|}
\hline Main magnate & Main regional allies \\
\hline \multicolumn{2}{|r|}{ Donn faction in Connacht } \\
\hline $\begin{array}{l}\text { O'Connor Donn of } \\
\text { Roscommon }\end{array}$ & $\begin{array}{l}\text { O'Hara of Leyny, O'Gara of Coolavin, MacDermot of Airteach, } \\
\text { O'Kelly of Hymany, O'Madden, O'Mulryan, O'Hanly, } \\
\text { O'Beirne, O'Rourke }\end{array}$ \\
\hline Burke of Clanrickard & Bermingham of Conmachy, O’Saughnessy, O’Heyne \\
\hline O’Connor of Sligo & $\begin{array}{l}\text { O'Dowd of Tireragh, MacDonnough of Tirrerrill Corran, } \\
\text { O'Rourke of West Breifne, MacJordan of Gallen, Barret of } \\
\text { Tirawley }\end{array}$ \\
\hline \multicolumn{2}{|r|}{ Ruadh faction in Connacht } \\
\hline $\begin{array}{l}\text { O'Connor Ruadh of } \\
\text { Roscommon }\end{array}$ & $\begin{array}{l}\text { MacDavid Burke of Clan Conway, MacCostello of Clan Costello, } \\
\text { MacDermot of Moylurg }\end{array}$ \\
\hline Burke of Mayo & $\begin{array}{l}\text { O'Malley of the Owles, O'Flaherty of Iar Connacht, Staunton, } \\
\text { Joyce, MacWattin }\end{array}$ \\
\hline
\end{tabular}

Nicholls and later adopted by Art Cosgrove. ${ }^{72}$ Both scholars have alluded to the existence of these networks in Connacht. However, the fact that these Connacht-based alliances developed into larger, competing aristocratic networks that eventually came to dominate nearly two-thirds of Ireland during the later fourteenth and early fifteenth centuries, remains hitherto unacknowledged in the historiography.

It is important to bear in mind that while this conflict stemmed from a civil war in Roscommon, hegemonic control of Connacht was, in reality, contested by the more powerful patrons of O'Connor Donn and O'Connor Ruadh, namely the competing Burke of Clanrickard and Mayo families (and eventually by the O'Briens, O'Donnells, and O'Neills). Initially this conflict had been confined west of the River Shannon, primarily to the province of Connacht. In the space of a few short years, however, it had spread to neighboring provinces of Ulster, Leinster, and Munster (see table 2 and figure 1). The reasons behind the expansion of this conflict lie in the geopolitical situation pertaining both to Connacht and the other provinces and to the political and territorial ambitions of the main magnates therein. The lords of western Leinster became drawn into the conflict in eastern Connacht partly due to power struggles in northern Leinster but also to maintain control of the Shannon. For example, the competing branches of the O'Ferralls of Annaly (the Clan Sean and Clan Aedh) sought support from O'Connor Donn/Burke of Clanrickard and O'Connor Ruadh respectively in an attempt to control this vital waterway. Further south, the O'Connors of Offaly, kinsmen of the O'Connor Ruadh kindred through marriage, acted as a check on O'Connor Donn and Burke of Clanrickard expansion in Leinster. For example, not only did the O'Connors of Offaly provide military support to O'Connor Ruadh when required but the O'Connors of Offaly

${ }^{72}$ Cosgrove, "Ireland beyond the Pale," 576-80; Nicholls, Gaelic and Gaelicized Ireland, 174. 
were later joined in marriage to the O'Donnells of Tyrconnell (see below) ${ }^{73}$ Another comparable situation existed in northern Munster. The O'Briens of Thomond, with the support of the Burkes of Clanrickard (both members of the Donn faction), emerged as the dominant regional powers and posed an ever greater threat to the towns of Limerick and Cork, as well as the authority of the earl of Desmond. ${ }^{74}$ Likewise the MacCarthys of Desmond, due to necessity, became increasingly drawn into the Donn/Ruadh struggle (see section 3).

Table 2-Donn/Ruadh allegiance beyond Connacht

\begin{tabular}{lc}
\hline Main magnate & Main regional allies \\
\hline O'Brien of Thomond & $\begin{array}{r}\text { Donn faction allies beyond Connacht } \\
\text { MacNamara of Clan Cullen, O'Loughlin of the Burren, } \\
\text { O'Connor of Corcomroe, MacMahon of Corkavaskin, Clan } \\
\text { William Burke, Mac Uí Bhrian of Ara } \\
\text { Maguire of Fermanagh, O'Cahan of Ciannachta, MacMahon } \\
\text { of Oriel, Bisset of the Glynns, O'Reilly of East Breifne }\end{array}$ \\
$\begin{array}{l}\text { Clan Sean O'Ferrall of } \\
\text { Annaly }\end{array}$ & $\begin{array}{r}\text { O'Donnell of Tyrconnell } \\
\text { O'Connor of Offaly } \\
\text { Clan Aedh O'Ferrall }\end{array}$ \\
\hline
\end{tabular}

The Ulster dimension to this conflict was perhaps the most significant and is essential in exploring why the O'Neills later wished to cooperate with Richard. As noted, the earlier fourteenth century witnessed a sustained period of O'Neill expansion in central and eastern Ulster. Following Aodh Reamhar's death in 1364, his son and successor, Niall Mór (d.1397) continued this process. ${ }^{75}$ By the early 1380s most of central and eastern Ulster had fallen under the control of the O'Neills, with Gaelic factions such as the Maguires, Clandeboy O'Neills, MacMahons, Magennises, and O'Hanlons, as well as kindreds of Anglo-Norman extraction, such as the Bissets of the Glynns, owing their loyalty to the O'Neills of Tyrone (though the Clandeboy O'Neills and the Magennises appear to have later joined with O'Donnell—see below). This powerful position rested both on the compliance of these lesser kindreds and on the relative cohesion of the wider Tyrone lordship. As with the Donn and Ruadh factions in Connacht, the allegiance of the smaller lordships, Maguires and MacMahons, was maintained through ties of dynastic politics including marriage alliances and fosterage but also enforced through military intimidation. Niall Mór and

${ }^{73} A C, A U, A L C$, AClon, AFM, 1406. AFM, $A U, 1433$.

${ }^{74}$ AFM, 1382; "Patent Roll 2 Henry IV, 23," CIRCLE: A Calendar of Irish Chancery Letter, c. 1244-1509, ed. Peter Crooks, Trinity College Dublin, https://chancery.tcd.ie/document/patent/2henry-iv/23.

${ }^{75}$ AFM, 1397. 
his heir designate, Niall Óg (d.1403), maintained their court in southeastern Tyrone or northern Armagh, either at Dungannon or Eamhain Macha (Navan Fort). ${ }^{76}$ From here they continued to expand O'Neill power in eastern Ulster and posed an ever greater menace to the northern borders of the Pale. The fulcrum of O'Neill power in this period, however, derived from the activities of another of Niall Mór's sons, Éinrí Aimhreidh (d.1392), and his ability to protect Tyrone from Turlough an Fhíona O'Donnell (d.1422), the lord of Tyrconnell.

Éinrí Aimhreidh's duty in defending the western approaches to Tyrone rested on the maintenance of large military forces - drawn from Tyrone and the Maguire lordship of Fermanagh - and the fomenting of dynastic unrest within Tyrconnell. The O'Neills' ability to play rival branches of the O'Donnells against one another in Tyrconnell formed the basis for O'Neill expansion in eastern Ulster during the 1360s and 1370s. ${ }^{77}$ For example, two of Niall Mór's daughters were married to rival claimants to the O'Donnell lordship; Gormlaith (d.1416) was married to Sean O'Donnell (d.1380) while her sister Gráinne was married to Turlough an Fhíona O'Donnell. ${ }^{78}$ Turlough an Fhíona seized power within Tyrconnell in 1380 and quickly came to pose a serious threat to O'Neill dominance in Ulster. ${ }^{79}$ Over the course of the early 1380s, the O'Donnells gradually began to reassert themselves; the conflict in Connacht came to play an increasingly important role in the O'Neill-O'Donnell struggle. In an attempt to flank the O'Donnells, Éinrí Aimhreidh sought assistance from the Donn faction in Connacht, allying himself with the O'Connors of Sligo and O'Rourkes of West Breifne-both of whose lordships bordered with southern Tyrconnell. ${ }^{80}$ These lordships held great strategic value: whoever controlled them could, in theory, control the passageways between Ulster and Connacht (see figure 1). Conversely, in order to ease pressure on his southern flank, O'Donnell reached out to the Ruadh faction in Connacht who could attack Sligo and West Breifne and draw Donn faction forces away from Tyrconnell.

It therefore comes as no surprise that Sligo and West Breifne became hotly contested combat zones over the next number of years as the O'Donnells, O'Neills and their respective Ruadh and Donn faction allies each jostled for control of these lordships. Indeed, the scenario in northern Connacht forced the Burkes of Clanrickard and the O'Briens of Thomond to participate more actively in central Connacht in order to draw the Ruadh faction away from northern Connacht. This strategy of tying the Ruadh faction down on a series of fronts initially proved successful. During the late 1380s and early 1390s, Éinrí Aimhreidh, in cooperation with his allies in Connacht, succeeded in containing the O'Donnell threat. This, in turn, enabled Niall Mór and Niall Óg to continue solidifying their hold upon eastern

\footnotetext{
${ }^{76}$ For location of O’Neill seat, see Simms, "Late Medieval Tír Eoghain,” 147.

${ }^{77}$ For O’Neill expansion, see $A C, A L C, 1366,1368,1370,1374 ; A U, 1362,1365,1367,1369,1370$; $A F M, 1365,1366,1368,1370,1375$.

${ }^{78}$ AC, AU, ALC, AFM, 1416; Paul Walsh, ed., The Life of Aodh Ruadh O Dombnaill, Transcribed from the Book of Lughaid O Clerigh, 2 vols. (Dublin, 1948, 1957), 2:158.

${ }^{79}$ AFM, 1380.

${ }^{80} A U, 1388 ; A L C, A F M, 1388,1389$. This alliance was sustained into the early fifteenth century. For example, in 1420 Éinrí Aimhreidh's son and successor, Domnall Bog (d.1432), was provided with shelter in Sligo during a period of internal strife in Tyrone; see $A C, 1420$. The alliance with Sligo was subsequently adopted by the main ruling line in Tyrone following Domnall Bog's death; see $A F M, A U, 1432$.
} 
Ulster-a prime example being the O'Neill assault upon the town of Dundalk on the north coast of Leinster in 1392 (see figure 2). ${ }^{81}$

The O'Donnells, however, had one major advantage in this broadening geopolitical conflict. Unlike Tyrone, Tyrconnell was a maritime lordship, and there is evidence to suggest that the O'Donnells were able to draw upon sizeable maritime resources, giving them a tactical advantage over their opponents. The importance of galleys and other seafaring craft in Gaelic Scottish warfare has been amply demonstrated. Galleys or smaller craft like birlinn enabled west Highland factions such as the MacDonald lordship of the Isles and Campbells of Loch Awe to dominate much of the western Scottish seaboard, patrolling strategic lochs and safeguarding trade routes and maritime passageways. ${ }^{82}$ Yet historians of Gaelic Ireland have tended to overlook the importance of the maritime landscape in late medieval Irish politics, a topic that to date has largely been the pursuit of marine archaeologists. ${ }^{83}$

The O'Donnells were noted for their ability to raise from among their sub-kindreds large military forces, including cavalry drawn from the O'Dohertys of Inishowen and light infantry or "kern" from the O'Gallaghers and O'Boyles of Boylagh. ${ }^{84}$ The three MacSweeny galloglass septs of Fanad, Banagh and na Doe, however, formed the backbone of O'Donnell armies. Originally hailing from Knapdale in western Scotland, the MacSweenys were displaced during the Scottish-Norse wars of the late thirteenth century and the Anglo-Scottish wars of the early fourteenth century. ${ }^{85}$ A maritime kindred, they quickly found shelter in Ireland and secured permanent employment as hereditary galloglass for successive O'Donnell chieftains; the Fanad branch emerged as the dominant MacSweeny grouping. From their coastal lordship in western Tyrconnell, the MacSweenys of Fanad not only provided their O'Donnell masters with heavy infantry but also maintained a small fleet of galleystyle craft. ${ }^{86}$ The tactical and logistical advantages of the MacSweeny fleet allowed the O'Donnells to intervene directly in Connacht, side-stepping any obstacles posed by the O'Connors of Sligo or the O'Rourkes of West Breifne.

As demonstrated elsewhere, the ability to intervene in far-flung regions of Gaelic Ireland would later prove essential to establishing the O'Donnell hegemony over much of northwestern Ireland in the late fifteenth and early sixteenth centuries. ${ }^{87}$ During the late fourteenth and early fifteenth centuries, maritime connections enabled the O'Donnells and MacSweenys to develop and strengthen the alliance

${ }^{81} A C, A U, A L C, A F M, 1392$.

${ }^{82}$ Stephen Boardman, "The Campbells and Charter Lordship in Medieval Argyll," in The Exercise of Power in Medieval Scotland, ed. Stephen Boardman and Alasdair Ross (Dublin, 2003), 95-117, at 115-17.

${ }^{83}$ Connie Kelleher, “The Gaelic O’Driscoll Lords of Baltimore, Co. Cork: Settlement, Economy and Conflict in a Maritime Cultural Landscape," in Lordship in Medieval Ireland: Image and Reality, ed. Linda Doran and James Lyttleton (Dublin, 2007), 130-59.

${ }^{84}$ Katharine Simms, "Late Medieval Donegal," in Donegal: History and Society, ed. William Nolan, Liam Ronayne, and Mairéad Dunlevy (Dublin, 1995), 183-202, at 187-89.

${ }^{85}$ Michael Brown, The Wars of Scotland, 1214-1371 (Edinburgh, 2004), 272; Nicholls, Gaelic and Gaelicized Ireland, 100-2.

${ }^{86}$ Darren McGettigan, "The Principality of Tír Chonaill in the Early Sixteenth Century," in An Historical, Environmental and Cultural Atlas of County Donegal, ed. Jim MacLaughlin and Seán Beattie (Cork, 2013), 135-47, at 144 .

${ }^{87}$ Simon Egan, "The Resurgence of Gaelic Power in Ireland and Scotland and Its Wider Impact" (PhD diss., University College Cork, 2016), 236-304. 
with the Ruadh faction in Connacht. Though composed in the early sixteenth century, the genealogical history of the MacSweeny dynasty, the Leabhar Chlainne Suibbne, recounts that by the early fifteenth century the MacSweenys had married into the O'Malleys of the Owles-another prominent seafaring kindred (see table 1 and figure 1). ${ }^{88}$ At the turn of the century, a large force of MacSweeny galloglass were serving alongside the O'Malleys in Connacht, with the O'Malleys also providing military support to the O'Donnells and MacSweenys in Tyrconnell when required. ${ }^{89}$ This arrangement effectively allowed the O'Donnells to resist encroachment from both the O'Neills of Tyrone to the east and the O'Connors of Sligo in the south. Maritime connections also enabled the O'Donnells to open a second front against the O'Neills in eastern Ulster; during the early fifteenth century, O'Neill of Clandeboy, O'Hanlon, and Magennis were each co-opted into an alliance with O’Donnell (see figure 2). ${ }^{90}$

The sea was important to the O'Donnells and their allies for two further reasons. The cooling of the climate in the fourteenth century resulted in the migration of vast herring stocks to the coasts of Ireland and Scotland. ${ }^{91}$ The influx of English, French, Spanish, and Dutch fishermen generated considerable prosperity for the Gaelic nobility. Using fleets, Gaelic kindreds such as the O'Donnells, (or the O'Malleys, the O'Driscolls, and the O'Sullivan Beare dynasties of south Munster), and the Campbells of Argyll imposed levies on visiting fishermen for fishing within their respective spheres of influence or for seeking shelter along the coast. ${ }^{92}$ The wealth generated by the fisheries enabled the Gaelic nobility to develop trading links with the rest of the British Isles and continental Europe. Over time the lords of the western Ireland built strong trading connections with insular ports such as Bristol and Glasgow as well as continental trading hubs including La Rochelle and Bordeaux (O'Donnell's soubriquet "an Fhíona"- "of the wine"-suggests he may have been personally involved in the trade). ${ }^{93}$ The O'Donnells also maintained a network of agents in many of these ports to safeguard their mercantile interests and also to carry and receive news, ${ }^{94}$ ensuring that the Gaelic "periphery" remained attuned to developments within the wider Atlantic world. ${ }^{95}$

The Irish intrigues of the later Stewart kings, James IV (d.1513) and James V (d.1542), particularly their relationship with the O'Donnells, has been the subject of recent scholarship. ${ }^{96}$ The O'Donnell-Stewart alliance of the late fifteenth and

\footnotetext{
${ }^{88}$ Paul Walsh, ed., Leabhar Chlainne Suibhne: An Account of the MacSweeny Families in Ireland, with Pedigrees (Dublin, 1920), 57, 63-65.

${ }^{89}$ For MacSweenys in Connacht, see $A U, A L C, A F M, 1413$. For O'Malleys in Ulster, see $A U, A F M$, $1413,1427$.

${ }^{90} A U, A L C, A F M, 1422$.

${ }^{91}$ Jim McLaughlin, Troubled Waters: A Social and Cultural History of Ireland's Sea Fisheries (Dublin, 2010), 93-120.

${ }^{92}$ See Mark Gardiner and Tom McNeill, "Seaborne Trade and the Commercialisation of Fifteenth- and Sixteenth Century Gaelic Ulster," Proceedings of the Royal Irish Academy C116 (2016): 229-62.

${ }^{93}$ Katharine Simms, "Niall Garbh O’Donnell, King of Tír Conaill, 1422-39," Donegal Annual 12 (1977): 8 .

${ }^{94}$ MacGettigan, "Renaissance Lordship," 206-7.

95 Egan, "Gaelic Resurgence," 18-21.

${ }^{96}$ Alison Cathcart, "James V, King of Scotland-and Ireland?," in World of the Galloglass: Kings, Warlords and Warriors in Ireland and Scotland, 1200-1600, ed. Seán Duffy (Dublin, 2007), 124 43; Norman MacDougall, James IV (Edinburgh, 2006), 116-20, 134, 198-200, 266-67.
} 
early sixteenth century was nonetheless, built upon much earlier foundations that can be tentatively traced to the early 1380s. Indeed, though it has received little scholarly attention, the O'Donnell's alliance with the Stewart monarchy runs like a leitmotiv through the history of late medieval Ireland. Evidence for the origins of this relationship is contained in the registers of the Avignon papacy. Recent years have witnessed a growing interest in the development of the church in late medieval Gaelic Scotland, including the impact of the Avignon papacy. ${ }^{97}$ Aside from a number of short studies, little research has been conducted on the Papal Schism's impact upon Gaelic Ireland. ${ }^{98}$ Though Edouard Perroy originally framed Richard's Irish expeditions as a crusade against the Clementist Irish, it has generally been assumed that the Avignon papacy had little impact upon Gaelic Irish politics. A reexamination of surviving sources suggests otherwise. ${ }^{99}$

The papal schism of the later fourteenth century further entrenched preexisting alliance blocs that had developed across Europe during the Hundred Years' War. Among those adhering to the Roman papacy of Urban VI (d.1389) were the English, the Flemish, the Danes, the Swedes, the northern Italian city states, the Poles, and the Hungarians. Conversely, Clement VII of Avignon (d.1394) was supported by the French, Castilians, and Aragonese, the kingdoms of Naples and Cyprus, and Scotland. In Ireland, there appears to have been a large support base for Clement VII in the dioceses of Raphoe, Killala, Clonfert, Clogher, and Annaghdown, with a lesser following in the dioceses of Tuam and Elphin. ${ }^{100}$ Raphoe, Killala, Clonfert, Annaghdown, and western Clogher were each controlled by lords of the Ruadh faction. Tuam and Elphin, on the other hand, were divided between the Donn and Ruadh factions, which may explain the resistance to Avignon influence there. ${ }^{101}$

A full reconsideration of the Avignon papacy's impact upon the wider HibernoScottish world remains a desideratum. Such an enterprise is made extremely difficult due to the limitations of surviving source material. While this article is not the forum for such an undertaking, there are nonetheless, a number of brief points to make in relations to the Scottish-Avignon interest in late fourteenth-century Ireland and how this ultimately shaped Richard II's security concerns regarding the island. The

${ }^{97}$ Iain MacDonald, Clevics and Clansmen: The Dicoese of Argyll between the Twelfth and Sixteenth Centuries (Leiden, 2013); Sarah Thomas, "Bishops, Priests, Monks and Their Patrons: The Lords of the Isles and the Church," in The Lordship of the Isles, ed. Richard Oram (Leiden, 2014), 123-45.

${ }_{98}$ Philip Daileader, "Local Experiences of the Great Western Schism," in A Companion to the Great Western Schism (1378-1417), ed. Joëlle Rollo-Koster and Thomas M. Izbicki (Leiden, 2009), 89-122, at 100-1; Aubrey Gwynn, A History of Irish Catholicism, vol. 2, Anglo-Irish Church Life in the Fourteenth and Fifteenth Centuries (Dublin, 1968), 51-64; Katherine Walsh, "Ireland, the Papal Curia, and the Schism: A Case Study," in Genese et Debuts du Grand Schismed'Occident (1362-1394), ed. Jean Favier et al. (Paris, 1980), 561-74.

${ }^{99}$ Charles Burns, "Papal Letters of Clement VII of Avignon (1378-94) Relating to Ireland and England," Collectanea Hibernica, no. 24 (1982): 7-44, at 8; Lydon, "Richard II's Expeditions," 216; Colman Ó Clabaigh, The Friars in Ireland, 1224-1540 (Dublin, 2012), 49-51; Eduoard Perroy, L'Angleterre et le Grand Schisme D'Occident: Etudé sur la Politique Religieuse de L'Angleterre sous Richard II, 13781399 (Paris, 1933), 102-3.

${ }^{100}$ Burns, "Papal Letters," 16-21, 24-25, 27-32. The bishop of Annaghdown was driven from his bishopric by the Gaelic Irish; see Petition of John Twilloe to Richard II, 1393, The National Archives of the United Kingdom (hereafter TNA), SC 8/215/10722.

${ }^{101}$ Burns, "Papal Letters," 16-21, 24-25, 27-32. 
possible adherence of the aforementioned dioceses and lordships to the Avignon papacy opened up a further international dimension to Irish politics. Material contained within the calendar of Avignon papal registers indicates that members of the Ruadh faction were in contact with the Scottish king through clerical intermediaries loyal to the Avignon papacy from 1379 onwards. While the greater number of petitions were sent directly to Avignon, it appears that some were forwarded to the Scottish court and were included in Robert II's correspondence with Clement VII in 1381. ${ }^{102}$ These petitions originally came from the O'Muldoons of Lurg and the O'Lennons of Lisgool, both located in the diocese of Clogher. ${ }^{103}$ While the political allegiance of the O'Lennons is more difficult to trace due to the fragmentary nature of source material, it is worth noting that the bishop of Clogher, John O'Corcrain, wrote to Richard II c.1380 informing the king that he had been driven from his bishopric; whether or not this was linked with Scottish/Avignon involvement in Clogher remains uncertain. ${ }^{104}$ The O'Muldoons, on the other hand, appear to have been allies of the O'Donnells and controlled a territory coexistent with the modern-day barony of Lurg. Their lands were, moreover, located north of the passes from Connacht into Ulster and were subjected to raids by members of the Donn faction (see figure 1). ${ }^{105}$

A pattern of communication between the O'Donnells and their allies and the Scottish monarchy appears to have developed over the next number of years. This is evident both from further material contained in Avignon registers and the broader context of Scottish activity in the wider Irish Sea world. In February 1383, the bishop of Glasgow, Walter Wardlaw (d.1387), was ordered by Clement VII to assist in removing the bishop of Killala, Robert Eliot, to put in place the Clementine favored candidate, Cornelius O'Connor. ${ }^{106}$ The following year Wardlaw was appointed Avignon papal legate for Ireland and Scotland with the intention of further undermining English and Roman papal influence in the northern Irish Sea world. ${ }^{107}$ Though Wardlaw died in 1387, there is evidence that his successor as bishop of Glasgow, Matthew Glendinning, maintained the connection with Ireland and in 1394 he secured a benefice in the diocese of Sodor for one "Maurice Nemie" of Raphoe diocese in Tyrconnell. ${ }^{108}$ The movement of Avignon clerics across the North Channel provided the Stewart monarchy with a direct line of contact to the O'Donnells of Tyrconnell. ${ }^{109}$ As noted, the early Stewart kings Robert II and Robert III (d.1406), in the mold of their ancestor Robert Bruce,

\footnotetext{
${ }^{102}$ For the full roll of Robert II in 1381, see W. H. Bliss, ed. Calendar of Entries in the Papal Registers Relating to Great Britain and Ireland: Petitions to the Pope 1342-1419 (London, 1896), 559-61.

${ }^{103}$ Ibid., 559.

${ }^{104}$ Petition of John O’Corcrain to Richard II, c.1377-c.1386, TNA SC 8/222/11071.

105 AC, ALC, 1400.

${ }^{106}$ W. H. Bliss and J. M. Twemlow, eds., Calendar of Entries in the Papal Registers Relating to Great Britain and Ireland: Papal Letters, 1362-1404 (London, 1902), 245-46.

${ }^{107}$ Charles Burns, ed., Calendar of Papal Letters of to Scotland of Clement VII of Avignon, 1378-94 (Edinburgh, 1976), 104-7. See also, MacDonald, Border Bloodshed, 83.

${ }_{108}$ Bliss, Calendar of Entries, 620. The identity of Maurice is uncertain.

${ }^{109}$ Other Ulster clerics also received benefices; see ibid., 575-76.

Clerics were often used to carry messages between the O'Donnells and Stewarts; see John Stuart et al., eds., The Exchequer Rolls of Scotland, 233 vols. (1878-1904), 4:585, 677.
} 
were acculturated to the Gaelic world and enjoyed strong relations with many Gaelic Scottish factions such as the Campbells of Loch Awe and Clan Donnchaidh of Atholl. Cultivating cordial relations with these lords was essential to the security of the Scottish kingdom, particularly from the 1380s onwards once the MacDonalds switched their allegiance to Richard II. These cultural and political ties to Gaelic Scotland acted as a bridge into Gaelic Ireland and allowed the Stewarts to develop an alliance with the O'Donnells. Indeed, though it is beyond the scope of this present article, there is evidence to suggest that the Campbells of Loch Awe may have developed links with the O'Donnells during this time. ${ }^{110}$

From the Scottish perspective, the alliance with the O'Donnells opened another front against the English in the western section of Ireland. This new theatre of military operations, in addition to aforementioned Scottish forays on eastern coast of Ulster and the Franco-Castilian raids on the south coast of Ireland, placed greater pressure on English military and financial resources. The O'Donnells could also contribute to the defense of Scotland, largely by tying English forces down in Ireland and, perhaps more importantly, by acting as a check on the MacDonalds. As noted earlier, it appears that by the early 1380s the Clan Alexander-the dynastic rivals of the lords of the Isles-had fragmented into smaller family branches. One of these branches migrated westwards, and by the early 1390s had found employment as galloglass under the MacDermots of Moylurg, who were members of the Ruadh faction and allies of Turlough an Fhíona O'Donnell. ${ }^{111}$ This branch also appears to have had links with the O'Donnells; in 1397 O'Donnell personally attempted to secure a permanent lordship for the Clan Alexander by displacing the O'Connors of Sligo (see below). Though this venture ultimately ended in failure, the prospect of the Clan Alexander possessing a permanent base of operations in Ireland can hardly have been welcomed by the lord of the Isles.

At the close of the fourteenth century, much of the northern two-thirds of Ireland had become divided into the two opposing camps. The death of Éinrí Aimhreidh in May 1392 placed greater pressure on Tyrone's western defenses. ${ }^{112}$ The same year, O'Donnell captured Éinrís son and successor, Domhnall Bog (d.1432), and only a combined attack led by Niall Óg O'Neill and O'Connor of Sligo contained the O'Donnell threat, albeit briefly, and secured Domhnall Bog's release. ${ }^{113}$ By 1395 O'Donnell and his Ruadh faction allies had made significant gains both in Ulster and Connacht. It is from within this context that the MacDonalds sought to strengthen their ties with the English monarchy against the O'Donnells and their growing attachment to the Stewarts. Likewise, the O'Neills of Tyrone and their Donn faction allies, faced with a powerful network of enemies within Ireland, sought greater recognition and protection under English law. For Richard, the willingness of these Gaelic factions to negotiate provided him with the opportunity not only to strengthen English power in Ireland but to reestablish across much of the

\footnotetext{
${ }^{110}$ Colin Campbell of Loch Awe was killed by O'Donnell's enemy Brian O'Connor of Sligo (d.1440) in Tyrconnell in early 1413; see $A F M, 1412$.

${ }^{111} A U, 1397 ; A L C, A F M, 1387,1398 ; A C, 1398 ;$ Nicholls, "Scottish Mercenary Kindreds," 100.

${ }^{112}$ AC, AU, ALC, AFM, Séamus Ó’hInnse, ed., Miscellaneous Irish Annals, 114-1437 (hereafter AMisc) (Dublin, 1947), 1392.

${ }^{113} A C, A U, A L C, A C L M, A F M, 1392$. Domhnall Bog later became ruler of Tyrone in 1404, something his father never achieved.
} 
wider British Isles a degree of influence that had not been seen since the military hegemony of Edward I (d.1307).

\section{RICHARD II IN IRELAND}

Dorothy Johnston has noted that Richard II may have considered leading an expedition to Ireland as early as 1389. The limitations of surviving English and AngloIrish governmental sources make the reasons behind this intent extremely difficult to discern. ${ }^{114}$ Having recovered his position from the Lords Appellant in late 1388, Richard was still focused on regaining his domestic standing, mainly by building ties with Wales, Chester, and other "peripheral" areas of his dominions. What is certain is that he regarded developments in Ireland as of great importance. ${ }^{115}$ This poses the question as to what extent he was aware of developments in Ireland, particularly in the Gaelic west.

Taken at face value, surviving Anglo-Irish and English sources suggest that the colonial nobility's knowledge of developments in the western section of Ireland was limited. Developments in western Ireland were, however, unlikely to appear in English patent or close rolls unless of direct concern to the colonial government. ${ }^{116}$ Yet Richard's actions in Ireland point to his having, at the very least, some understanding of the significant geopolitical shift then occurring in the western section of Ireland and the growing level of Avignon and Scottish influence there. Indeed, much of Richard's intelligence on affairs in western Ireland may have derived from the colonial earls who, as Robin Frame has outlined, had successfully adapted to frontier life in fourteenth-century Ireland. ${ }^{117}$ James Butler, third earl of Ormond, for example, not only acted as interpreter for Richard during the submission of numerous chieftains but, according to Froissart, played an important role in persuading the most powerful chieftains to submit. ${ }^{118}$ An investigation of the Richard's initial military campaign, coupled with an analysis of the submissions themselves, and the context of specific grants made to individual Gaelic lords, in turn, suggest that Richard was more informed on Gaelic affairs than is evident in surviving chronicle sources.

As noted in the introduction, the threat posed to colony's southern defenses by Art MacMurough-Kavanagh (d.1416/17) has attracted considerable scholarly attention. The course of Richard's successful campaign, culminating in Art's submission on 7 January, has been dealt with elsewhere. ${ }^{119}$ Richard's success against the MacMurrough-Kavanaghs coupled with the sheer military might of his forces has long been regarded as one of the chief reasons why the other Gaelic lords felt compelled to submit (see table 3). ${ }^{120}$ If this threat of force was indeed a factor, then it pertained

\footnotetext{
${ }^{114}$ Johnston, "Richard II and the Submissions," 3.

115 Tuck, Richard II and the Nobility, 170.

116 For example, see $R C H, 170 \mathrm{n} 74,185 \mathrm{n} 68$; CPR, Richard II, 4:405; "Patent Roll 2 Henry IV, 23," CIRCLE.

${ }^{117}$ For an overview of adaptability, see Frame, "Power and Society," 191-220.

118 Johnes, Froissart's Chronicles, 156-57.

119 Curtis, Richard II in Ireland, 185-86, 189-90; Lydon, "Richard II's Expeditions," 225-28; Emmet O'Byrne, War, Politics, and the Irish of Leinster, 1156-1606 (Dublin, 2003), 110-12.

${ }^{120}$ Cosgrove, Late Medieval Ireland, 20-22; Frame, Political Development, 215; Lydon, Lordship of Ireland, 233; Lydon, "Richard II's Expeditions," 228; Otway-Ruthven, Medieval Ireland, 328.
} 
mainly to the submissions of the Gaelic and rebel Anglo-Irish lords in Leinster, where the proximity of the royal army was more visible. For example, Murchadh O'Connor of Offaly (d.1421) — a member of the Ruadh faction—is recorded as being on the

Table 3-Chief nobles who submitted to Richard II $^{121}$

\begin{tabular}{|c|c|}
\hline Magnate/family & Factional allegiance \\
\hline \multicolumn{2}{|l|}{ Ulster } \\
\hline $\begin{array}{l}\text { Niall Óg O’Neill, on behalf of his father, Niall Mór O’Neill, } \\
\text { lord of Tyrone }\end{array}$ & Donn faction \\
\hline $\begin{array}{l}\text { Philip Ruadh, lord of Oriel, and his brothers, Shane and } \\
\text { Aedh MacMahon }\end{array}$ & Donn faction \\
\hline $\begin{array}{l}\text { *John O'Reilly, lord of East Breifne, his brother Giolla } \\
\text { Íosa, and his cousin Maolmórdha O'Reilly }\end{array}$ & Donn faction \\
\hline Magnus O'Cahan, lord of the Ciannachta & Donn faction \\
\hline MacCabe of Clogher, captain of galloglass & $\begin{array}{l}\text { Family served O'Reilly and } \\
\text { MacMahon; Donn faction }\end{array}$ \\
\hline John MacDonald, captain of Niall Mór O’Neill's galloglass & O'Neill of Tyrone; Donn faction \\
\hline $\begin{array}{l}\text { Muirchertach Óg Magennis, lord of Iveagh, and his } \\
\text { brother, Cú-Uladh Magennis }\end{array}$ & Hostile to O’Neill \\
\hline $\begin{array}{l}\text { Cú-Uladh, son of Eachmharcach O'Hanlon of Orior, and } \\
\text { Niall O’Hanlon }\end{array}$ & Hostile to O’Neill \\
\hline Adam MacGilmore of Down & Uncertain \\
\hline
\end{tabular}

Connacht

Turlough Óg O’Connor Donn, lord of Roscommon Domhnall O'Connor, lord of Sligo

WIlliam Burke of Clanrickard

Donn faction

Donn faction

Donn faction

O'Connor Donn submitted on behalf of the following:

Donn faction

Barret of Tirawley, Bermingham of Conmachny, Mac-

Donnough of Tirrerrill, O'Dowd of Tireragh, O'Kelly of Hymany, O'Madden, O'Mulryan, MacDermot of Airtech, O'Hanly, O'Beirne, O'Flannagan, O'Rourke of West Breifne

\begin{tabular}{ll} 
Brian O'Brien, lord of Thomond & Munster \\
O'Brien submitted on behalf of the following chieftains: & Donn faction \\
O'Loughlin of the Burren, O'Dea, O'Connor of Cor- & Donn faction \\
comroe, O'Hehir, MacMahon Corkavaskin, MacNamara & \\
of Clancullen, MacGorman & \\
Tadhg MacCarthy, lord of Desmond & $\begin{array}{c}\text { Allied to Earl of Desmond and } \\
\text { Donn faction }\end{array}$ \\
Tadhg O'Meaghar, lord of Ikerrin & $\begin{array}{l}\text { Hostile to Earl of Ormond; } \\
\text { allied to Art MacMurrough- }\end{array}$ \\
& Kavanagh \\
\hline
\end{tabular}

Continued

${ }^{121}$ For a full list, see Curtis, Richard II in Ireland, 57-225; Curtis, "Unpublished Letters," 276-303; Myles V. Ronan, "Some Medieval Documents," Journal of the Royal Society of Antiquaries of Ireland 7, no. 2 (1937): 229-41. 
Table 3-Continued

\begin{tabular}{ll}
\hline Magnate/family & Factional allegiance \\
\hline & \\
Murchadh O'Connorter & \\
Diarmuid & Ruadh faction \\
Niall O'Molloy, lord of Fercall & \\
& Allied to O'Connor of Offaly; \\
Ruadh faction & Allied to O'Connor of Offaly; \\
Conor O'Melaghlin, lord of Kineleagh & Ruadh faction \\
Art MacMurrough-Kavanagh of Leinster & Uncertain \\
**Murchadh Bán O'Ferrall, chief of the Clan Sean branch, & The Clan Sean were allied to the \\
and his kinsmen, Thomas and Rossa O'Ferrall & Donn faction \\
Gerald O'Byrne, lord of Críoch Branach, and his cousin & Allied to MacMurrough- \\
Donnchadh O'Byrne & Kavanagh \\
Tadhg O'Carroll, lord of Ely & Allied to Earl of Ormond \\
\hline
\end{tabular}

* Submitted to Roger Mortimer at Trim in late 1394

** Submitted both to Mortimer in late 1394 and Richard in spring 1395

receiving end of sustained English assault; hence his submission to Richard (see table 3). ${ }^{122}$ In comparison, the terrain of the Gaelic heartlands stretching from Thomond on the Atlantic seaboard to the northern coasts of Ulster presented a foreboding obstacle to Richard's army. The king would have been faced with a powerful coalition of Irish chieftains in the Donn faction had he decided to march north in an attempt to force their submission. That scenario was unlikely, considering that Richard's army was needed to secure Leinster and prevent Art MacMurrough-Kavanagh from breaking his peace. The activities of Richard and the lords of the Donn faction suggest instead that both parties hoped to achieve a mutually beneficial arrangement.

Accompanying Richard on this expedition were a number of prominent English noblemen, chief among them Roger Mortimer (d.1398), fourth earl of March and the greatest absentee landlord in Ireland. In addition to his expansive estates in England and southeast Wales, Roger had inherited the earldom of Ulster and lordships of Connacht, Trim, and Meath from his father, Edmund, third earl of March (d.1381). ${ }^{123}$ The recovery of these estates was of paramount importance to Richard and fitted into the aforementioned strategy of strengthening English power in the "peripheral" areas of the British Isles. ${ }^{124}$ Richard had already developed a link between the MacDonalds and Mortimer through the earl's tenants, the Savages, and their marriage into the Bisset affinity. The remainder of Mortimer's Irish lands were largely controlled by members of the Donn faction (although

122 Curtis, Richard II in Ireland, 167, 189, 193, 209-10; AFM, 1395.

123 Simms, "Revolt of 1404," $144-45$.

${ }^{124}$ Mortimer was granted livery of his Irish lands in June 1393; see CPR, Richard II, 5:284. See also Tuck, Richard II and the Nobility, 172-73. 
Burke of Mayo, O'Donnell, and O'Connor Ruadh each held segments of the Mortimer lands). The O'Neills of Tyrone controlled most of Mortimer's lands in Ulster, though other segments were held by the O'Cahans, MacMahons, O'Neills of Clandeboy, O'Hanlons, and Magennises. The O'Reillys of Breifne, O'Ferralls, MacGeoghegans, and O'Kearneys each bounded parts of Mortimer's patrimony in southern Ulster and northern Leinster, while Mortimer's lands in Connacht were controlled primarily by the Burkes of Clanrickard and the O'Connor Donn dynasty (see table 3). ${ }^{125}$

Roger Mortimer's father, Edmund, had previously tried to recover these lands during his tenure as lord deputy of Ireland (1379-81). Though Edmund had some initial success in acquiring the submissions of Niall Mór O'Neill, O'Ferrall, MacGeoghegan, O'Kearney, O'Hanlon, Magennis, and O'Reilly, his heavy-handed tactics (such as the burning of large areas of eastern and southern Ulster) pushed many Gaelic lords into rebellion. ${ }^{126}$ Following Edmund's death in 1381, the Dublin government was unable contain O'Neill incursions into eastern Ulster and northern Leinster. Carrickfergus was burned in 1384, while Dundalk was suffered two major O’Neill raids in 1387 and 1392 (see figure 1). ${ }^{127}$ For Richard, it was clear that military action against the lords of the Donn faction would yield minimal results. By negotiating with these lords, he stood a better chance of recovering of recovering the Mortimer inheritance; moreover, the establishment of strong, cordial relations with these lords would greatly bolster English influence across the northwestern section of the island and limit the potential for Scottish intervention in Ireland.

Richard thus strove to build stronger links between the lords of the Donn factions, the colonial administration, and the crown. He secured a greater degree of legal protection for the submitted lords by defining their legal status before the Irish Council, issuing pardons for past offences, and knighting the more powerful lords-Niall Óg, Brian O’Brien (d.1400), Turlough Og O'Connor Donn, and William Burke of Clanrickard (d.1423) (as well as Burke's regional ally, Walter Bermingham). ${ }^{128}$ The knighthoods bound these lords closer to the king; the case of O'Connor Donn is particularly important. In addition to being admitted to English law (placing him, in the words of one scholar, within Richard's "charmed circle"), O'Connor Donn was also granted the constabulary of Roscommon Castle. ${ }^{129}$ Once a bastion of English power west of the Shannon, Roscommon Castle had been lost to the O'Connors since the 1350s; Richard's grant, however,

125 Simms, "Revolt of 1404," 144-45. In late 1394, Mortimer received the submissions of John O'Reilly (d.1400), lord of East Breifne (RCH, 165, no. 233), and O'Ferrall of Annaly (AMisc, 1394). See table 3 .

${ }^{126} A U, A F M, 1380$; Simms, "Revolt of 1404," 144-45.

${ }^{127} A U, 1384 ; A C, A C l o n, 1387, A F M, 1387,1392$. The capture of Niall Óg O’Neill in 1389 bought the colonists some badly needed breathing space; see $A C, A U, A L C, A C l o n, A F M, 1389$; Cal. Pat. 138892, 404 .

128 Curtis, Richard II in Ireland, 186-87, 214-16.

129 Jocelyn Otway-Ruthven, "The Background to the Arrest of Sir Christopher Preston in 1418," Analecta Hibernica 29 (1980): 71-94, at 78, 91-92. For "charmed circle," see John Gillingham, "Killing and Mutilating Political Enemies in the British Isles from the Late Twelfth to the Early Fourteenth Century: A Comparative Study," in Britain and Ireland, 900-1300: Insular Responses to European Change, ed. Brendan Smith (Cambridge, 1999), 114-34, at 128n68. 
went beyond simply acknowledging the castle's current occupant. ${ }^{130}$ Within the broader context of the submissions, the grant served to bolster O'Connor Donn's position against his main rival, Turlough O'Connor Ruadh, the main ally of O'Donnell and a supporter of the Avignon papacy in Connacht. Furthermore, when taking the submission of the Donn faction, Richard used clerics loyal to Rome as intermediaries and messengers (such as the bishops of Kilfenora and Kilmacduagh). Further, to prevent these lords' breaking the king's peace, he bound most of them to various sums of money before the representative of the Roman papal camera, Francis de Capanago. ${ }^{131}$ The promotion of the Roman Church, in turn, served to limit the influence of Avignon and therefore the Scottish crown in Gaelic Ireland.

Ultimately, it was the fear of a Scottish attack on northern England that convinced Richard to return home, leaving Waterford on 15 May 1395. ${ }^{132}$ Traditionally, his expedition of 1394-95 has been regarded as a failure, owing to the necessity of a second expedition in 1399, one that effectively ended his reign. Richard's Irish settlement was nonetheless made unworkable for two main reasons: the territorial ambitions of the earl of March and his ally Ormond, and the activities of O'Donnells. Surviving letters indicate that sometime in late 1394, Niall Óg O’Neill, O’Brien, O'Connor Donn, and Tadhg MacCarthy (d.1428) of Desmond discussed the prospect of submitting. ${ }^{133}$ O'Brien and O'Connor Donn were reluctant to submit to Richard and attempted to convince O'Neill of the same. ${ }^{134}$ The reasons for their hesitancy are uncertain. It is likely that both lords were anxious at the possibility of a renewed English presence in the west - a region where English influence had been defunct for nearly fifty years. O'Brien and O'Connor Donn also appear to have been faced with significant opposition from their regional allies, the most notable of them being Domhnall O'Connor (d.1395), lord of Sligo-a supporter of O'Connor Donn (see figure 1). ${ }^{135}$ Unlike most other colonial towns lost to the Gaelic Irish, Sligo remained a functioning borough with a lucrative maritime trade. Domhnall may have feared that a renewed English presence in the west would have undermined his control of the port town. ${ }^{136}$ By late January 1395, Niall Óg O’Neill was engaged with highly sensitive talks with Richard. Unwilling to tolerate any opposition, Niall Óg threatened to attack Domhnall O'Connor unless he acquiesced and submitted to Richard. ${ }^{137}$ While Niall Óg's threat of military intervention in Sligo ultimately secured Domhnall's compliance, the O'Neill aggression demonstrates how lesser families (such as the O'Connors of Sligo) were often expendable in the hands of more powerful lords.

\footnotetext{
${ }^{130}$ For grant, see Otway-Ruthven, "Arrest of Christopher Preston," 78.

${ }^{131}$ Curtis, Richard II in Ireland, 90-93, 113-14. De Capanago had been appointed by Boniface IX in 1393 and was granted a license by Richard II to execute the office of papal collector there. CCR, Richard II, 5:311, 225; Foedera, 7:751.

132 The English Council had been calling for Richard's return since February 1395; see POPC, 1:57-59. See also MacDonald, Border Bloodshed, 126-27.

${ }^{133}$ Curtis, Richard II in Ireland, 221-23.

${ }^{134}$ Ibid., 143-44.

135 Ibid., 214.

${ }^{136}$ For west coast trade, see Gardiner and McNeill, "Seaborne Trade," 229-62.

137 Curtis, Richard II in Ireland, 214.
} 
Tadhg MacCarthy's concerns regarding his submission related to developments in the southern half of Ireland, particularly Munster (see figure 1). ${ }^{138}$ James Butler, earl of Ormond, and Gerald FitzGerald (d.1398), third earl of Desmond had been feuding since the early 1380s. ${ }^{139}$ The Mortimers had been allies of the Butlers since the late 1370s, and Roger Mortimer naturally aligned himself with Ormond to gain leverage within Irish politics. ${ }^{140}$ As Peter Crooks has suggested, Ormond used his influence with Roger and Richard to have the king's cousin - Edward Albemarle (d.1415), earl of Rutland-created earl of Cork. ${ }^{141}$ Ormond's ploy effectively drove a wedge into Desmond's power base, forcing MacCarthy to acknowledge the authority of Rutland rather than Desmond as his immediate overlord. ${ }^{142}$ Though MacCarthy eventually agreed to this arrangement and received a knighthood from Richard, he first met with the lords of the Donn faction to discuss the prospect of submission. ${ }^{143}$ Melaghlin O'Kelly (d.1402), lord of Hymany and a member of the Donn faction, presented a similar case. Writing to Richard II in March 1395, he expressed his fears that Ormond, under the guise of Richard's authority, was about to seize lands held by O'Kelly's kindred since the early fourteenth century. ${ }^{144}$ O'Kelly also informed Richard that as a security measure to counter Ormond, he had enlisted the support of the earl of Desmond's son, John (d.1399). ${ }^{145}$

Brendan Smith has suggested that Mortimer was more adept at negotiating frontier life in Ireland than perhaps has been acknowledged. ${ }^{146}$ A great lord of the AngloWelsh marches, Mortimer enjoyed strong relations with both his English and Welsh tenants-not unlike his ally Ormond and his ability to uphold English power in Ireland while at the same time engaging with Irish culture. ${ }^{147}$ Mortimer was also a patron of the Welsh poet Iolo Goch (d.1397). In a famous poem addressed the earl in early 1394, Iolo Goch extolled Mortimer's martial prowess and encouraged him to subdue the "Ulster dog"-Niall Óg O’Neill. ${ }^{148}$ Mortimer's desire to "get his rents" from the Irish of Ulster, however energetic, placed great strain upon Richard II's Irish settlement. ${ }^{149}$ In January 1395, Niall Óg wrote to Richard beseeching him to be his "shield" against the ambitions of the young earl.150 The O’Neills were willing to reach a settlement with Mortimer and agreed to surrender

\footnotetext{
${ }^{138}$ A marriage between Tadhg MacCarthy's son, Domhnall (d.1468), and Ulick Burke of Clanrickard's daughter, Sadhb (d.1468), was also orchestrated sometime in the early fifteenth century; see ALC, 1468.

139 See Crooks, "Calculus of Faction," 115.

${ }^{140}$ For overview of Butler-Mortimer relations, see Peter Crooks, "Factionalism and Noble Power in English Ireland, 1361-1421” (PhD diss., University of Dublin, 2007), 201-43.

${ }^{141}$ Curtis, "Unpublished Letters," 123-24; Crooks, "Factionalism and Noble Power," 217-18.

${ }^{142}$ Curtis, "Unpublished Letters," 123-24; Curtis, Richard II in Ireland, 67-68.

143 Ibid., 221-23.

${ }^{144}$ Ibid., 122.

145 Ibid., 122-23, 204-3; Crooks, "Factionalism and Noble Power," 215-16.

${ }^{146}$ Brendan Smith, "Dressing the Part in the Plantagenet Empire: The Death of Roger Mortimer, Earl of March and Ulster, in 1398," in The Plantagenet Empire, 1259-1453: Proceedings of the 2014 Harlaxton Symposium, ed. Peter Crooks, David Green, and W. Mark Ormrod (Donington, 2016), 232-47.

${ }^{147}$ Ibid., 242-44.

${ }^{148}$ Eurys I. Rowlands, "Iolo Goch," in Celtic Studies: Essays in Memory of Angus Matheson, ed. James Carney and David Greene (London, 1968), 124-46, at 125. For identification of "Ulster dog" as Niall Óg, see Simms, "Revolt of 1404,” 148, 159n37.

149 AClon, 1394.

${ }^{150}$ Curtis, Richard II in Ireland, 210-12.
} 
the buannacht (the billeting of soldiers on local populations) of Ulster to him. ${ }^{151}$ Relations between the O'Neills and Mortimer, however, soured the following year. Having been appointed lord deputy of Ireland by Richard (though his jurisdiction was limited to Ulster, Connacht and Meath; Sir William Scrope had had powers over Munster, Leinster, and Louth), Mortimer, with the support of Ormond and the earl of Kildare, attacked the O'Neills, O'Reillys, and O'Ferralls, burning Armagh and its cathedral in the process before raiding the Magennis territory of Iveagh and killing the heir to the lordship, Cú-Uladh. ${ }^{152}$ These attacks, though aimed at cowing the O'Neills and the Irish of eastern Ulster, achieved relatively little. Mortimer's actions instead had a ripple effect upon the western section of Ireland, one that was ruthlessly exploited by O'Donnell and his allies.

Niall Mór and Niall Óg's fixation with Richard in the east left western Tyrone vulnerable. An O'Donnell-fomented civil war in the Maguire lordship of Fermanagh in early 1395 created a distraction that Turlough an Fhíona used to raid western Tyrone, capturing Brian (d.1402), brother of Domhnall Bog (see figure 1). ${ }^{153}$ A second attack orchestrated by O'Donnell's ally Burke of Mayo on the Donn faction in western Connacht drew the O'Connors of Sligo westwards, enabling O'Donnell to launch a devastating raid upon the Sligo lordship (see figure 1). ${ }^{154}$ With Brian held captive, there was little Domhnall Bog could to do to withstand O'Donnell. The lack of assistance from his cousin, Niall Óg, appears to have pushed Domhnall Bog into rebellion. By late 1395, he is recorded as leading an attack on Niall Óg's caput (possibly either Dungannon or Navan Fort), taking both his son and heir designate, Brian Óg, and wife, Úna, captive, before handing Úna over to the English. ${ }^{155}$ While the annals do not identify Una's new captors, it is possible that they were handed over to Mortimer as a stark warning to Niall Óg to devote greater resources to war against O'Donnell.

Niall Og was spurred into action. In early 1396, he ransomed Brian from O'Donnell, subsequently handing him over to Domhnall Bog in exchange for his own son, Brian Óg (d.1403). ${ }^{156}$ By this time, Niall Óg was under assault from Mortimer in the west and unable to take further action against O'Donnell. Over the course of 1396, O'Donnell launched a number of assaults upon Sligo, eventually driving Murtagh Bacach O'Connor (d.1403)-brother and successor of Domnall O'Connor-from his lordship in early 1397.157 The Donn faction were now stretched on a series of fronts: O'Donnell in the north and Mortimer pressing on Tyrone and Annaly, while O'Connor Ruadh defeated an army led by O'Connor Donn in central Connacht (see figure 1). ${ }^{158}$ O'Donnell now sought to establish full control of Sligo, installing his grandson Tadhg O'Connor (d.1403) as lord of Sligo and granting a segment of the lordship to the Clan Alexander (see

${ }^{151}$ For bonnacht, see ibid., 85-90, 173-90; M. Dominicia Legge, Anglo-Norman Letters and Petitions from All Souls MS 182 (Oxford, 1941), 210-11; Smith, Crisis and Survival, 82-83; Otway-Ruthven, Medieval Ireland, 328-29.

${ }^{152}$ AMisc, 1396. For appointments, see Otway-Ruthven, Medieval Ireland, 335n51.

153 AFM, 1395.

154 Ibid.

155 Ibid.

156 AFM, 1396.

157 Ibid.

${ }^{158}$ AFM, ACLM, AMisc, 1396. 
figure 1). ${ }^{159}$ It was only bickering among Tadhg O'Connor's men and the Clan Alexander over the division of lands, and a surprise counterattack by Murtagh Bacach that saw O'Donnell's forces driven from the region, enabling Murtagh Bacach to regain control of Sligo by early $1398 .{ }^{160}$ Despite this victory, a considerable amount of damage had been done. Domnall Bog had briefly refused to support Niall Óg against O'Donnell in 1397, effectively giving O'Donnell a free reign in the west. Though Domnall reconciled with Niall Óg in 1398, divisions had been sown between the two dominant O'Neill kindreds in Tyrone. This growing rift would eventually lead to the outbreak of both civil war and a succession crisis in Tyrone during the early fifteenth century (see below).

From the perspective of the crown, the situation in Leinster was little better. Mortimer's attacks on the Gaelic Irish of Ulster and Ormond's activities in Munster made it very difficult for the recently submitted chieftains to remain within the king's peace. Though Dorothy Johnston has argued that Leinster was at peace during 1395-98, evidence contained in the Irish annals suggests a very different state of affairs. ${ }^{161}$ Tensions between the Gaelic Irish of Leinster and northeastern Munster increased following a botched attempt at capturing Art MacMurrough-Kavanagh in late 1395. ${ }^{162}$ Art's allies, the O'Tooles, are recorded as inflicting a heavy defeat upon English forces in 1396. ${ }^{163}$ Though colonial troops, perhaps in retaliation, burned the monastic site of Glendalough in the Wicklow Mountains during the summer of 1398, the O'Connors of Offaly succeeded in capturing Gerald FitzGerald (d.1432), earl of Kildare, the same year. ${ }^{164}$ The English position in Leinster was to suffer a further blow later in the year. Despite a brief spell of royal disfavor, owing largely to the activities of his uncle, the Appellant Sir Thomas Mortimer (d.1397), Roger Mortimer was reconciled with Richard and reappointed to his Irish lieutenancy in April 1398-only to perish two months later while campaigning against the O'Byrnes in Carlow. ${ }^{165}$

Prior to Mortimer's death Richard had become increasingly concerned about the situation in Ireland and announced his intention to lead a second expedition there in the autumn of $1397 .{ }^{166}$ Whether or not the king was genuinely interested in securing a suitable compromise between the crown and the main Irish lords-the O'Neills and Donn faction in particular - remains a matter of debate. ${ }^{167}$ Mortimer's death and Kildare's capture in 1398 nonetheless forced Richard's hand regarding Ireland,

\footnotetext{
159 Tadhg was the son of Cathal Óg O’Connor (d.1362), and Gráinne was the daughter of Turlough an Fhíona; see $A F M$, 1396, AU, ACLM, AFM, AMisc, 1397.

${ }^{160} A U, A C L M$, AFM, AMisc, 1397.

${ }^{161}$ Johnston, "The Interim Years," 173-79.

162 AFM, 1395.

163 AFM, 1396.

164 ALC, 1398; AFM, AClon, 1398.

165 Crooks, "Factionalism and Noble Power," 227. This lieutenancy was rescinded soon after; see CPR, Richard II, 6:336, 402, 406; Chris Given Wilson, The Chronicle of Adam of Usk, 1377-1421 (Oxford, 1997), 40-41. For reconsideration of Mortimer's killing, see Smith, "Dressing the Part," 232-47.

166 CCR, Richard II, 6:154, 157.

167 Dorothy Johnston has pointed toward Richard's commitment in "The Interim Years: Richard II and Ireland, 1395-1399," in England and Ireland in the Later Middle Ages, ed. James Lydon (Dublin, 1981), 173-91. For a contrary view, see Crooks, "English Imperialism," 33-40; Smith, Crisis and Survival, $85 n 68$.
} 
and the following year, on 1 June 1399, Richard landed at Waterford. ${ }^{168}$ Unlike his venture of 1394-95, this expedition proved a military disaster. Richard was soundly beaten by Art MacMurrough-Kavanagh at every turn. The subsequent outbreak of Henry Bolingbroke's rebellion forced Richard to return to England, only to be deposed by the new king in October 1399.169 The vacuum created by Mortimer's death and Richard's sudden departure allowed Art MacMurrough-Kavanagh to reassert his position in southern Leinster. Mercenaries raised from Munster enabled him to push northwards through Wicklow, while an alliance with Maurice, de facto fifth earl of Desmond, opened a second front against Art's main regional ally, James, earl of Ormond. ${ }^{170}$

The situation in Leinster was but one in a series of problems faced by the new Lancastrian administration in Ireland and the wider Irish Sea world. Mortimer's earlier raids on Ulster, followed by the outbreak of civil war in Tyrone, seriously damaged the O'Neills' relationship with the colonial government in Dublin. It would take years and the strong leadership of Niall Óg's son, Eoghan (d.1456), to rebuild this relationship. Internecine feuding in Tyrone would facilitate the rise of Turlough an Fhíona's son, Niall Garbh (d.1439), who would come to dominate northern Irish affairs until the early 1430s. The consolidation of O'Donnell power in this period, coupled with the outbreak of Owain Glyn Dŵr's rebellion in Wales, in turn exposed large areas of the Irish and Welsh coastlines to French and Scottish intervention. While Glyn Dŵr's son, Maredudd ab Owain, finally surrendered to Henry V (d.1422) and accepted a pardon from the king in April 1421, the situation in Ireland played out somewhat differently. ${ }^{171}$ It was largely thanks to the intervention of Alexander, lord of the Isles (d.1449), that Niall Garbh was defeated and the earlier O'Neill hegemony restored. ${ }^{172}$

\section{CONCLUSION}

Richard II was the last English head of state to lead military operations in Ireland until Oliver Cromwell in 1649. In an age when the "first English Empire" of the thirteenth and earlier fourteenth centuries was entering a period of protracted decline, Richard's Irish expeditions represented a concerted and pragmatic attempt to reverse the "ebb tide" of English power and build stronger links with the more "peripheral" areas of the British Isles. The decline of English power within the wider British Isles during this period, coupled with England's increasing entanglement in France during the Hundred Years' War, has seen an increasing number of scholars gravitate toward the "Plantagenet" model when exploring the development of English royal power in the later Middle Ages. Nonetheless, it is important to locate Richard's Irish ventures within the broader archipelagic context and to utilize a

\footnotetext{
168 Curtis, "Unpublished Letters," 297-98.

${ }^{169}$ For a reassessment, see Douglas Biggs, Three Armies in Britain: The Irish Campaign of Richard II and the Usurpation of Henry IV, 1397-1399 (Leiden, 2006).

${ }^{170}$ For MacMurrough-Kavanagh expansion, see O'Byrne, Irish of Leinster, 113-15.

${ }^{171}$ Davies, Owain Glyn D̂̂w $r, 293$.

172 Simon Egan, "The Early Stewart Kings, the Lordship of the Isles, and Ireland, c.1371-1433," Northern Studies 49 (forthcoming).
} 
regional approach when considering both the English crown's relations with the archipelago's constituent regions and the political development of late medieval Britain and Ireland as whole-the dynamic relationship between elements of Gaelic Ireland and Gaelic Scotland in particular. As a case study, this article has, on one level, offered new insights into Richard's relationship with lords of the wider Gaelic world. On another level, it has demonstrated the necessity of paying closer attention to the Gaelic west as a force within "British" politics. Although the socalled Celtic fringe remains a geographically peripheral region of late medieval Ireland and Britain, developments there could impact and impinge upon the English and Scottish world during both the later Middle Ages and well into early modern periods. The Gaelic world's ability to influence the course of "British" politics and its capacity to destabilize the kingdoms of England and Scotland in these eras however, have yet to be fully appreciated. 